\title{
Savings: The Policy Debate in
}

Europe

Axel Börsch-Supan and Agar Brugiavini

18-2002

February 2002 


\title{
Savings: The Policy Debate in Europe
}

\author{
Axel Börsch-Supan and Agar Brugiavini \\ MEA, Department of Economics and SFB 504, University of Mannheim, Germany, \\ and National Bureau of Economic Research, Cambridge, Massachusetts \\ Department of Economics, University Ca' Foscari, Venice, Italy, \\ and Institute for Fiscal Studies, London, UK
}

\section{Paper Prepared for the Special Issue of "Oxford Review of Economic Policy"}

\begin{abstract}
Three issues dominate the public policy debate over savings in Continental Europe. First, can private savings substitute for public pensions in the provision of retirement income, given that the current generosity of pay-as-you-go financed pensions is hardly sustainable in the light of population ageing? And if so, which policy steps have to be taken to alleviate this transition? Second, does the evolution of a "new financial landscape" in Europe necessitate policy response in terms of taxation and regulation, specifically considering the increase in pension funds? And third, closely related to the other two issues, is there too much or too little saving in an ageing Europe? Will pension reform and the new financial landscape increase or decrease overall saving? Do we need to subsidise saving more or less than we currently do? The paper reviews economic theory and empirical evidence on these intertwined issues. Most importantly, it identifies many gaps in our theoretical and empirical knowledge that caution us against overly strong policy recommendations.
\end{abstract}

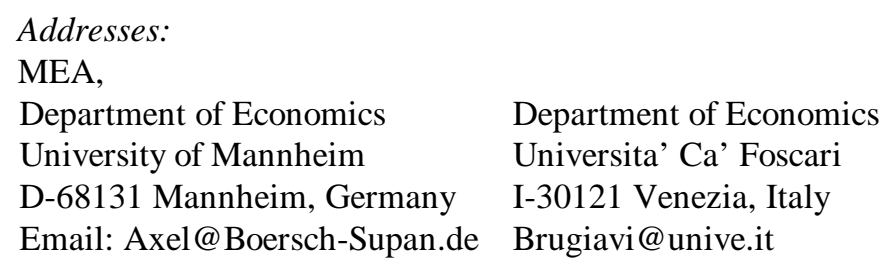

This paper has profited greatly from comments by James Banks and two anonymous referees. We appreciate the financial support by the Deutsche Forschungsgemeinschaft (Sonderforschungsbereich 504) and by the EU (TMR-Project ,Savings, Pensions and Portfolio Choice“). 


\title{
Savings: The Policy Debate in Europe
}

\author{
by Axel Börsch-Supan and Agar Brugiavini
}

\section{Introduction}

Saving is the provision for future consumption. We do not know how this future will look like. Four developments, however, are most likely to forcefully influence savings in Europe. First, almost all countries in Europe will experience population ageing to an extent that is historically without precedence. This will put the established pay-as-you-go financed social security systems under pressure and precipitate the need for more own provision by private savings. Second, life will become more colourful - the classical breadwinner model with one single but lasting job for life is becoming less dominant as the typical life course. Most likely, we will see more mobility, both across sectors, regions, and, through European integration, across countries, as well as between dependent and self-employment. This will increase uncertainty and the need for more flexible buffers than traditional public insurance. Third, society's views about the role of the state in providing social security - meant in this broad sense of providing a buffer, a social safety net - is rapidly changing: away from paternalistic provision financed by taxes towards delivery of services financed by contributions that ought to be fair in an actuarial sense. Hence, social insurance will be in more immediate competition with private insurance, and private insurance - hence, private savings - is likely to have more weight in the future. These developments interact with the fourth secular development, the evolution of a "new financial landscape" in Europe. This new landscape features a huge increase in the number and sophistication of financial instruments. Moreover, thanks mainly to the European Monetary Union and the introduction of the Euro, the financial landscape has become truly European rather than national.

None of these developments is new, and none limited to Europe. Social security systems are under pressure around the world, and the emergence of a new financial landscape is part of the globalisation of capital markets. The consequences of these developments, however, are only slowly recognised in Europe, and public policy reacts very cautiously, at least in Continental Europe. This is in contrast to the strong role that public policy plays in shaping saving behaviour. These policies include capital taxation and subsidies to specific forms of saving, regula- 
tion of capital markets, and, most notably, the design of pension systems and of the other branches of the social safety net.

While each country has specific debates over these policies, three common issues seem to dominate the political debate over savings in Continental Europe. The first issue is the perennial discussion about the role of private savings versus public provision in order to supply oldage income, health care, long-term care etc. Specifically, can private savings substitute for public pensions in the provision of retirement income, given that the current generosity of payas-you-go financed pensions is hardly sustainable in the light of population ageing? And if so, which policy steps have to be taken to alleviate this transition? Which side effects are to be expected?

A second common issue across Europe that might necessitate policy response concerns the evolution of a "new financial landscape". It is closely linked to the previous issue. Many observers claim that the sheer volume and the desire for high returns of the capital invested for private old-age provision requires more efficient capital markets than those we are used to in Continental Europe. Many of the instruments necessary to accommodate private old-age provision are still underdeveloped. France, Germany and Italy, to name the three largest Continental economies, have very small pension fund and annuity markets. In turn, pension reform may have side effects on capital markets by pushing up the share of funds that flow through institutional investors. The integration of financial markets in Europe, notably the abolition of exchange rate risks within the Euro zone, might help to diffuse risks associated with private pension scheme. The release of liquidity constraints and the further development of credit markets are likely to improve consumer welfare by enabling more intertemporal substitution. In turn, the emergence of the new financial landscape has intensified the debate on the necessity and the extent of cross national harmonisation in the areas of taxation and regulation.

Finally, a third recurrent issue is the question whether there is too much or too little saving, today and in the future when Europe is ageing. Do we need to subsidise saving more or less than we currently do? Which kinds of assets should be tax preferred? Obviously, these issues are closely linked to the first two issues: ageing and pension reform will affect the volume of saving, and so does a change in the financial landscape of Europe. In turn, whether there is too much or too little saving in an economy has profound implications on the optimal design of a pension system. 
These three intertwined issues are the topic of this paper on savings and public policy in Europe. We collect and review the pieces of economic theory and empirical evidence that are at our disposal in order to shed light on the choices public policy has; we also try to identify the gaps in our theoretical and empirical knowledge in order to caution against overly strong policy recommendations.

The paper is structured as follows: Section 2 discusses issues centring around pension reform and its implications for saving. Section 3 describes the "new financial landscape" that appears to emerge in recent years, how it affects saving, and the policy issues relating to it. Section 4 looks at the related but more general question whether saving rates in Europe are too low (or too high) and how saving rates will evolve when the European population ages. Section 5 concludes: what policy advice can economists give about savings? What is known? Where do we need more data and research? The one conclusion we can anticipate is that the empirical evidence on the links between policy actions and saving behaviour is scanty and inadequate in Europe. Most significantly, Continental Europe lacks longitudinal data sets of the type existing in the U.S. which have allowed researchers and policy makers to deepen their understanding of saving behaviour and the interactions between policy decisions and individuals' choices.

\section{Savings and Pension Reform in Europe}

Let us again begin with the trivial but important insight that saving is the provision for future consumption. ${ }^{1}$ It is hard if not impossible to attribute precise amounts of savings to specific types of future consumption. It seems, however, that the provision for old age is the single most important purpose, paralleled only by the need to save for homeownership. Providing for old age can be done through the capital market via explicit saving or through the state via the pay-as-you-go (PAYG) pension systems (and possibly through a mixture of the two). Thus, one of the most - if not the most - important interaction between savings and policy is centred around pensions; specifically, on how savings and the ongoing or impending pension reform attempts in Europe rely on, and might affect, savings. This is the topic of this section.

Today, the mixture between PAYG and funded old-age provision varies quite remarkably across countries. This is shown in the bottom rows of Table 2.1. In most Continental European countries, notably in the three largest countries France, Germany and Italy, the PAYG mecha- 
nism is the most important instrument. There are notable exceptions, however, such as the Netherlands and Switzerland. ${ }^{2}$

Table 2.1: Level and Sources of Retirement Income

\begin{tabular}{lcccccccc}
\hline & D & F & I & E & NL & CH & GB & US \\
\hline Replacement $^{\text {a }}$ & $82 \%$ & $79 \%$ & $80 \%$ &.$/$ & $78 \%$ & $81 \%$ & $69 \%$ &.$/$ \\
\hline First Pillar $^{\mathbf{b}}$ & $85 \%$ & $51 \%$ & $74 \%$ & $92 \%$ & $50 \%$ & $42 \%$ & $65 \%{ }^{\mathrm{c}}$ & $45 \%$ \\
Second Pillar $^{\mathbf{d}}$ & $5 \%$ & $34 \%$ & $1 \%$ & $4 \%$ & $40 \%$ & $32 \%$ & $25 \%$ & $13 \%$ \\
Third Pillar $^{\mathrm{f}}$ & $10 \%$ & $15 \%$ & $25 \%$ & $4 \%$ & $10 \%$ & $26 \%$ & $10 \%$ & $42 \%{ }^{\mathrm{g}}$ \\
\hline
\end{tabular}

Notes: (a) All income sources of average two-person retiree household just after retirement as percent of total income of average two-person household just before retirement. (b) Public retirement income (public pensions, social assistance, civil servants' pensions, etc.) as percent of total income of two-person retiree household. (c) In Great Britain, first pillar income also includes SERPS. (d) Private occupational pension income as percent of total income of two-person retiree household. (e) In France, almost all second pillar income is pay-as-you-go financed. (d) All other retirement income (asset income, net transfers received, earnings, etc.) as percent of total income of two-person retiree household. (g) 25 percentage points of this figure are earnings.

Sources: Disney et al. (1998), Gruber and Wise (1999), Börsch-Supan and Miegel (2001).

In spite of these differences, the top row of Table 2.1, based on Disney at al. (1998), shows an astounding similarity in the overall replacement rates. Adding up the income from all pillars, we find that households just after retirement receive approximately $80 \%$ of the income they enjoyed shortly before retirement. This replacement rate is nearly identical in Germany, France, Italy, the Netherlands, and in Switzerland; it is slightly lower in Great Britain.

The combination of these two findings suggests a strong substitution among the three pillars, that is, for a strong adaptation of the private individual and employer-based old-age provision to the public pension system. Econometric studies based on time-series in Germany, the Netherlands and the US (see the evidence quoted in Subsection 2.2) and the cross national comparison of savings patterns in Börsch-Supan $(2001 \mathrm{a}, \mathrm{b})$ tend to confirm this impression although it always has been surrounded by a heated academic as well as political debate.

One actually has to carefully distinguish two kinds of substitution even: (1) substitution between bequethable wealth and wealth that is annuitised for retirement, and (2) substitution

\footnotetext{
${ }^{1}$ Possibly even of future generations - through bequests.

${ }^{2}$ Some Nordic countries, which we do not discuss in this paper, also have hybrid systems.
} 
within "retirement wealth". ${ }^{3}$ Both substitution mechanisms are important in the pension reform discussion, and we discuss them separately in the subsections that follow. In fact, while all forms of private saving (whether annuitised or not) constitute private wealth accumulation, and are usually recorded that way in national accounts, the difference between bequeathable (fungible) wealth and retirement wealth rests on the basic motives for saving. Hence, in theoretical models or in simulation exercises one is usually concerned with describing changes in total capital accumulation (i.e. total private wealth even if annuitized), but in the empirical work the extent of substitutability is usually assessed by comparing bequeathable wealth on the one hand and retirement wealth (or just public retirement wealth) on the other.

This section focuses on this interaction between savings and pension reform. We do not provide a comprehensive discussion on pension reform, this is not the topic of this paper ${ }^{4}$.

The first subsection addresses the question, how much private saving needs to be substituted for PAYG-financed retirement income provision in order to stabilise the current PAYG system contribution rates (this is the second substitution mechanism). Subsection 2 is devoted to possible crowding-out effects vis-à-vis other savings (the first substitution mechanism). We then ask in subsection 3, which policies are required, if any, to induce the necessary amount of savings. Finally, subsection 4 discusses the risks involved in a reformed pension system and the policies to minimise these risks.

\subsection{How much private saving will be needed to stabilise PAYG pensions?}

Pension reform is a major policy issue in the countries of Continental Europe. As pointed out in the introduction, they face a common problem: their populations are ageing, and this especially quickly from the year 2010 on. The dependency ratios - the demographic parameter of most importance for the old-age-pension systems - will about double, particularly so in Italy and Germany, thereby also about doubling the financial burden of the PAYG pension systems. Since solutions within the PAYG systems are limited in light of this doubling of the burden, almost all pension reform attempts in Europe also make use of the only mechanism that can attain greater flexibility, namely spreading the demographic burden over a longer time horizon

\footnotetext{
${ }^{3}$ Bernheim (1987a and b) first addressed this issue.

${ }^{4}$ For a description and discussion of recent reforms see Feldstein (1998), Disney (1996 and 2000), OECD (2000a), BörschSupan and Miegel (2001), Brugiavini and Fornero (2001), Disney and Johnson (2001).
} 
by pre-funding. ${ }^{5}$ How much saving for old age is necessary to stabilise the PAYG fiscal burden $?^{6}$

We use Germany as an example for a numerical calculation of the volume of pre-funding necessary to stabilise the PAYG contribution rate. Of course, this depends on the policy mix. We carry out a partial equilibrium analysis and assume the following scenario. First and within the PAYG system, the effective retirement age will be increased by 3 years and the contribution rate frozen. Second, a pre-funded second pillar finances the emerging ageing burden. Concretely, at the end of year 2001, it is announced that the contribution rate will be frozen from year 2008 on at the then current level. Because population ageing increases the dependency ratio, this implies a reduction in the replacement rate - a "pension gap" will emerge. We assume that this pension gap will completely be filled by pre-funding such that the sum of future reduced PAYG pension benefits and new funded pensions will remain equal to the current PAYG pension benefits. ${ }^{7}$

This bookkeeping exercise implies that in response to the increasing dependency ratio, the benefits provided by the frozen PAYG system will shrink to two-thirds of what they are now. Hence, new funded pensions eventually have to provide for about one third of current PAYG benefits. Adding the existing other sources of retirement income (see Table 2.1), the balance between PAYG and other sources will create a mix in Germany similar to what it is now in the Netherlands and Switzerland. In countries that age less than Germany (e.g. France), the funded share will be lower, while in countries that age more (e.g. Italy), the funded share will be higher if such a freezing policy is applied.

How much new saving is needed in order to provide a third of current pension income? This mainly depends on the instruments used and their rates of return. We design an instrument

\footnotetext{
${ }^{5}$ Privatisation and pre-funding are often used to describe the move toward funded systems. However, they are associated with two different aspects: privatisation is the creation of funded individual accounts, pre-funding means closing the gap between social security benefits promised to date and the assets on hand to pay for them. One can easily imagine combinations of privatisation and pre-funding during the transition to a partially funded system, ands this is exactly what is simulated in the sequel.

${ }^{6}$ Parametric reform steps within the PAYG system, in particularly an increase in the retirement age, can go a long way in stabilising future contribution rates. Unlike to the UK, however, they cannot absorb all the burden in the countries most affected by population ageing. Germany, for example, would need a shift of the average retirement age by 9.5 years in order to fully compensate the increase in the dependency ratio, see Börsch-Supan (2000).

7 Hence, we only look at the $85 \%$ of retirement income that is currently provided for by the first pillar, see Table 2.1. Details of this and related transition models can be found in Birg and Börsch-Supan (1999).
} 
similar to a group life insurance which covers all three biometric risks (longevity, disability and survivorship) and is paid out on retirement as an annuity. For the sake of simplicity our computations are based on a standardised life course, in which gainful employment begins at age twenty and ends at age 60 (in 2000), the latter gradually increasing to age 63 (in the year 2035). We apply the upper variant of the life expectancy projections used by the most recent government computations. Hence, this insurance covers the individual risk of longevity as well as this projected aggregate increase of longevity. Early disability occurs between age 45 and 60 with an increasing probably averaging 15 percent, the current frequency. Survivor benefits are paid in accordance to the average current probabilities which is likely to be an overestimate because an increasing share of women will have their own pensions. ${ }^{8}$

The pension or insurance company is investing the accumulated capital in the market using a broad portfolio of stocks, bonds, direct placement and real estate. We assume that this portfolio generates the average gross rate of return that prevailed between 1980 and 1995 in the industry. This was $6.5 \%$ in real terms - however, we will also vary this rate in our projections. We subtract administrative costs of $6 \%$ of contributions, the average for group insurance policies. ${ }^{9}$ Here enters the significance of the group policy: past experience has shown that individual accounts tend to have higher administrative costs. Group policies and a universal spread of pre-funding "enforced" by the notional account mechanism also minimises the costs of adverse selection in the annuity market. We do not propose additional incentives or mandatory contributions but a consistent taxation of all retirement benefits together with tax deductibility of all pension contributions.

The resulting net rate of return to the customer is $4.5 \%$ in real terms. One may find this overly optimistic, but we think that the experience between 1980 and 1995 is a fairly good indicator of the future - it includes the "golden years" of the mid1990s as well as the Asian and other financial crises. Nevertheless, we also present simulations with a slightly higher (5.5\%) and a substantially lower real rate of return (3.0\%). We assume that this rate will decline in the wake of population ageing to $4.2 \%$ in 2035 , and then remain constant. This estimate is based on the growth model of Section 3 that simulates the effect of population ageing and the feedback of a partially funded pension system on capital intensity and the rate of return.

\footnotetext{
${ }^{8}$ In this case, Germany has a partial offset rule which reduces total claims.

9 Administrating individual policies is more expensive. This is why we choose group policies that can be bun-
} 
Figure 2.1 shows the path of savings and PAYG contributions under the proposed mixed and under the current pure PAYG system for a representative worker. For each birth cohort, it compares the total contributions in the transition scenario - the frozen contributions to the remaining PAYG system (the lower part of the bars, denoted by 1) plus the savings invested in the group account (upper part of the bars, denoted by 2) - with the contributions in a continued PAYG system (3, solid line). The transition smoothens the increase of the total contribution rate relative to the PAYG system, and prevents the total contribution rate from reaching the peak burden of the PAYG system after the year 2035 without changing pension benefits. For cohorts born after about 1970, the transition results in substantially lower total contributions than under the PAYG system.

Figure 2.1: PAYG Contributions and Savings Implied by Pension Reform (DM/month at the average wage)

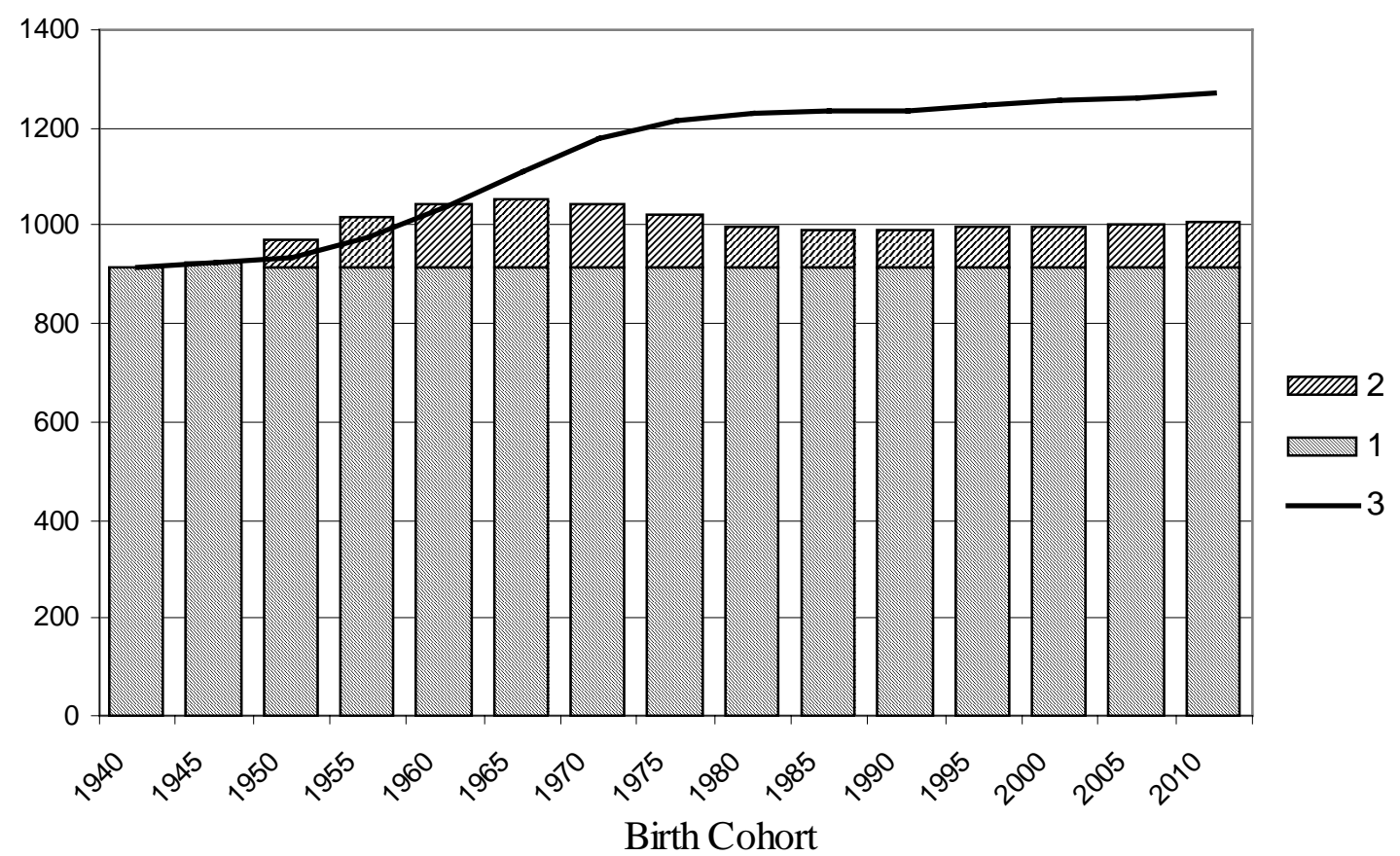

Note: 1000 DM are approximately 500 US-\$ at PPP. The Figure shows PAYG (1) and savings (2) contributions to the mixed system and the PAYG contribution to the old pure PAYG system (3). Replacement rate fixed at the level of 1997. Real rate of return is 4.5\%. Source: Birg and Börsch-Supan (1999). 
Note the cohort dependency of savings in Figure 2.1. Unlike to current government proposals or the Swedish model, the freezing model implies a higher savings rate for the cohorts born around 1965 than earlier or later cohorts. This is most clearly shown in Figure 2.2. The earlier cohorts need to fill a smaller gap, while the later cohorts have longer time to exploit the force of compound interest. The implied saving rate (i.e., contributions to new pension accounts, expressed as a percentage of gross wages to be compatible to the PAYG contribution rates) is highest for the 1965 cohort and reaches about $3.2 \%$.

These simulations are sensitive with respect to the assumed rate of return. Figure 2.2 shows the variation. If rates of return are lower, saving rates need to make up and increase. The peak rate will reach $4.7 \%$ at a $3 \%$ real rate of return, but is only $2.5 \%$ at a $5.5 \%$ rate of return.

Figure 2.2: Implied Saving Rates

(\% of gross income)

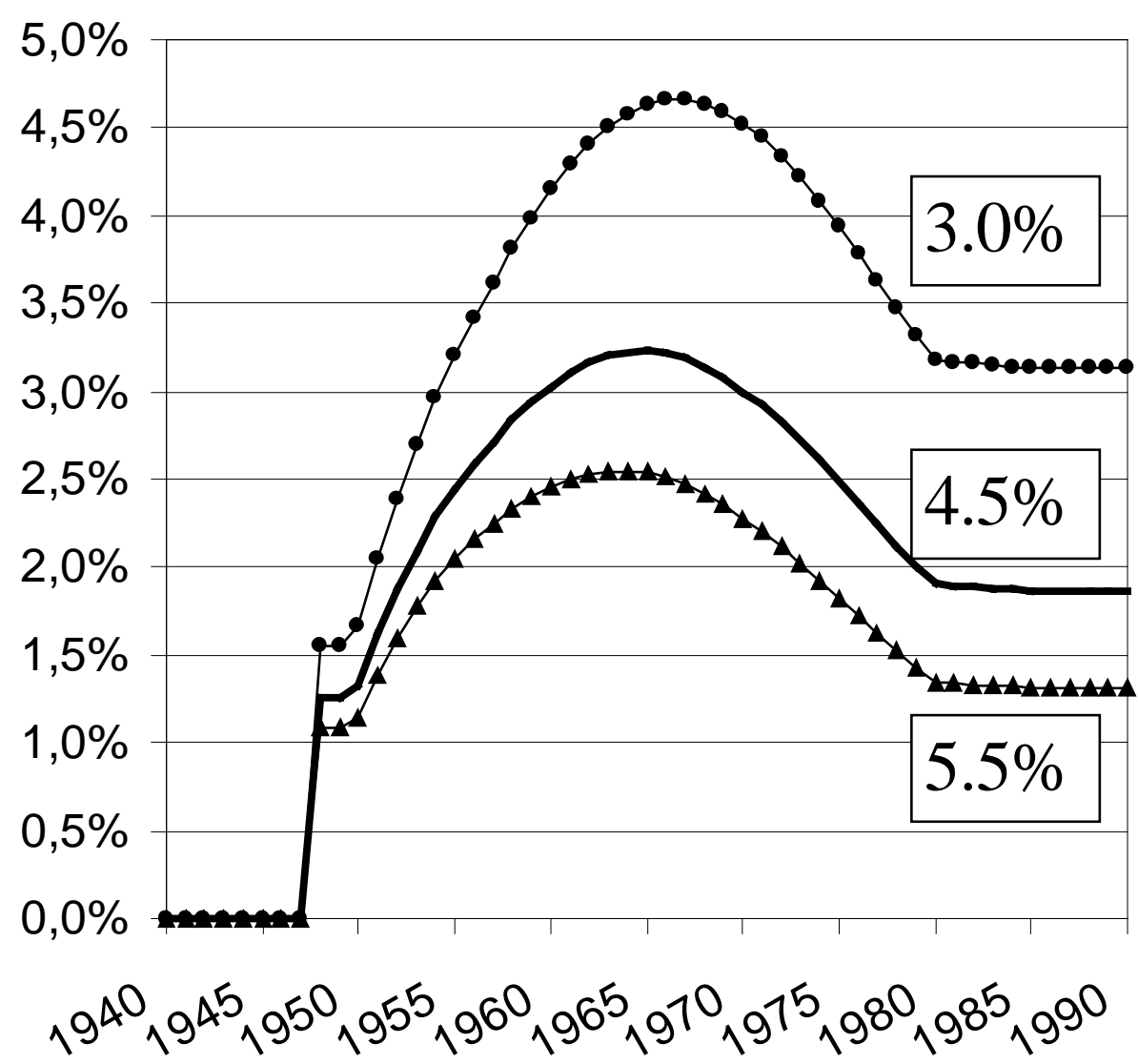

Birth Cohort

Source: Birg and Börsch-Supan (1999). 
The upshot of this simulation is that the private saving rate has to increase by 1.8 percentage points in the long run if the creation of a pre-funded second pillar are the main policy response to population ageing (in addition to an increase in the retirement age by 3 years). If one believes in lower future rates of return, say, $3 \%$ rather than the $4.5 \%$ assumed, the private saving rate has to increase by slightly more than 3.2 percentage points. Applied to the 1965 cohort, the saving rate has to increase from some $12.1 \%$ (1998) to $13.9 \%$ or $15.3 \%$, depending on the rate of return. Even this larger figure is well in the realm of the historical variation in German household saving rates.

As we argued before, extrapolating this simulation to France and most other European countries will generate a smaller gap to be filled than in Germany because Germany is projected to experience one of the highest increases in the dependency ratio in Europe. It will, however, be surpassed by Italy. In this country, households will have to save more than the Germans in order to fill the corresponding pension gap.

\subsection{Crowding out}

It is unlikely that all of the additional saving depicted in Figure 2.2 will be new saving since some other saving will be "crowded out" by the new saving for pre-funded retirement income. For example, people may buy smaller homes (and thus save for a smaller down payment) when they have to pay more for their retirement. This "crowding out" is the first of the two substitution mechanisms that we mentioned in the outset of this section.

Crowding out is an important policy issue for two reasons. First, a central argument put forward in pension reform discussions is the macroeconomic superiority of a funded system vis-àvis a PAYG system. ${ }^{10}$ This argument is valid only to the extent that new savings is created which adds to the capital stock and therefore promotes economic growth. This requirement holds a fortiori when the transition costs of a pension reform are considered. Second, if prefunding is incensed by tax relief, full crowding out implies that these subsidies are merely windfall gains that shift existing savings from one form to another. We discuss the first point here and the second in the following subsection.

\footnotetext{
10 Macroeconomic superiority refers to a de novo system. Welfare superiority including transition costs requires additional effects over and above this capital accumulation, strengthening the necessity of new saving. See Börsch-Supan (1999), Breyer (2000) and Sinn (2000) for an exchange on this point.
} 
The extent of crowding out is subject of the famous debate between Feldstein (1974) and Barro (1974). Our reading of the controversy is that we do not have reliable estimates of the quantitative extent, but that the evidence supports a positive effect on total savings when the PAYG system is reduced, e.g., in a partial transition as described in the previous subsection. We do not have reliable econometric estimates because crowding out takes place by the behavioural adaptation of generations, thus needs long periods of time, in which many other macroeconomic circumstances change.

Auerbach and Kotlikoff (1983) pioneered the discussion on the difficulties with the identification of the substitution parameters both in time series and cross sectional studies for the US. The structural instability of the parameters is due to the changes in population structure and to the fluctuations in interest rates as well as in contribution rates during the transition after the introduction of a new pension system.

For Europe the empirical evidence is scanty and there exists a wide variety of results, making it particularly hard to reach any conclusion. To our knowledge time series studies include Rossi and Visco (1994) ${ }^{11}$ for Italy, who are able to attribute part of the decline occurred during the 1980 s in the saving rate to the increased generosity of the social security in the 1970s. In other countries the relationship between pension wealth and private fungible wealth emerging from time series data is poorly determined ${ }^{12}$. Cross sectional analysis based on Italian micro data (Brugiavini, 1987; Jappelli, 1995) obtain low estimates of the substitution parameter. Recent studies for the Netherlands obtain mixed results. In particular, by using the Dutch Socio Economic Panel (SEP) data on private wealth and on (constructed) data on social security wealth and pension wealth, Alessie, Kapteyn and Klijn (1997) and Kapteyn, Alessie and Lusardi (1999) have investigated the question whether or not there exists displacement between discretionary private wealth on the one hand and social security and pension wealth on the other hand. For pension wealth they do not find any evidence of displacement, while for social security wealth they find full displacement ${ }^{13}$.

\footnotetext{
11 The studies are based on long run relationships between, saving, growth and changes in public pension wealth.

12 See Kohl and O'Brien (1998) for a detailed survey.

13 See also Euwals (2000). The evidence based on cross sectional data for the USA (Hubbard, 1986) and for Canada (King and Dicks-Mireaux, 1982), is also rather mixed.
} 
Clear cut "experiments" in which the pension system changes but everything else remains constant, are hard to come by. Attanasio and Brugiavini (1997) rely directly on a test of how changes in saving rates are related to changes in pension wealth following the 1992 Reform of the Italian Social Security System in a "quasi-natural-experiment" setting. They find that households whose public pension wealth was substantially curtailed by the reform show a marked increase in their private saving rate.

Given this lack of conclusive econometric evidence, we have inferred the extent of crowding out from an overlapping generations (OLG) model drawn from Börsch-Supan, Heiss and Winter (2001). This OLG model was calibrated to German data and implies a substitution of about one third, leaving two thirds new saving. This estimate is fairly robust for a reasonable variation in the underlying parameters, so it is probably a good guess for other countries as well. However, it is based on the tight structure of an OLG model. We refer the reader to the third part of section 3.2 for a discussion of the limits of this tight structure and possible implications.

\subsection{Which kind of incentives are likely to create this saving?}

Related to the issue of crowding out is the effect of savings incentives. In most pension system transition that have occurred in recent history, the transition was supposed to be speed up by tax relieves for private old-age provision.

Economic theory is ambiguous on the effect of tax subsidies on the volume of private savings because the substitution effect (higher after tax returns make saving more attractive than consumption) has an impact opposing that of the income effect (the subsidy increases total income which increases consumption in all periods). Moreover, the interpretation of the available evidence is hotly debated, see especially the controversy between Venti and Wise (1990) on one side, and Gale and Scholz (1994) and Attanasio and De Leire (1994) on the other side, referring to the effects of tax subsidies on American households' retirement saving and discussing the "creation" of new saving. The issues are summarised by Skinner and Hubbard (1996) for the US and by Attanasio and Banks (1998) for a comparison of the US and the UK.

In Continental Europe, this debate is complicated by the fact that in some cases households seem to be "overannuitized". Evidence by Börsch-Supan and Stahl (1991) and Börsch-Supan $(1992,1994)$ shows that the annuity income of a majority of pensioners (mostly PAYG income provided through the public system) by far exceeds consumption expenditures. The next gen- 
eration of pensioners appears to be aware of this fact, since saving rates in Germany drop for the now middle aged cohorts. Given this trend, a reduction in public pension wealth may not necessarily be channelled into new savings, or only after a transition period of new costly learning. At the same time, these households, if left to their own devices, may also shun pension assets because they do not want to lock their wealth into long term saving for retirement. This debate teaches two lessons. First, we do not really know whether saving-related tax relief or similar subsidies increase total saving. Second, we do know that subsidies strongly increase saving in the specific form that is subsidised, possibly to the detriment of other saving forms, see first point.

One has to bear in mind that only if the major motive for saving is saving for retirement, then households would value forms of savings that are close substitute for pension-assets, but which are typically illiquid. Furthermore the sheer variety of tax treatment of private pensions across Europe totally blurs the picture on which type of taxes may encourage or discourage different types of assets. $^{14}$

The U.S. experience, summarised by Wise (2001), has also taught us two further lessons. First, tax relief is not everything. The great success of individual retirement accounts (so-called "IRAs") and employer-sponsored retirement saving plans (so-called "401(k) plans") also seems to be due to information and advertising, and a consistent capital market regulation that reduced the uncertainty of investors. This is in great contrast to the UK experience, summarised by Disney (1996), where the lack of regulation and information led to the so-called mis-selling scandals that undermined investment in private accounts. In this scandal, inappropriate financial products were sold to households, often by door-to-door salespersons, resulting in huge financial losses to many families. State intervention seems necessary to provide for a smooth working of the capital market. We postpone a discussion of regulatory issues concerning pension funds and life insurance companies to Section 3.1 of this paper.

The second lesson from US experience is that tax relief only works for the upper two third of the income distribution. Neither IRAs nor 401(k) plans will have a noticeable impact on future retirement income of the lower third of the income distribution. In Germany and in Italy, these observations have sparked an extended discussion on whether to make private provision man-

\footnotetext{
14 See Dilnot (1992), World Bank (1999) and Börsch-Supan and Lührmann (2000) on the variety of pension taxation rules in Europe and elsewhere.
} 
datory. The argument pro obligatory savings is mainly the need to cover all persons in order to avoid pockets of poverty and to prevent moral hazard. The arguments against mandatory savings essentially rest on the well known economic efficiency arguments against taxation. One advantage of private savings for old age as opposed to PAYG contributions is that the latter have mainly tax character (Börsch-Supan and Reil-Held, 2000), therefore create dead weight losses, while private saving does not. Making saving mandatory, however, introduces an element of force, thus shifts savings understood as voluntary insurance premia towards mandatory taxes.

The issue is complicated by moral hazard. As long as the government provides pension income of last resort, voluntary savings is a waste - from the individual point of view, at least among those in the lowest parts of the earnings distribution - if one can just as well apply for social assistance. People may therefore opt for mandatory savings in order to reduce moral hazard. Boeri, Börsch-Supan and Tabellini (2001) actually find that most workers in France, Germany, Italy and Spain prefer a pension reform with mandatory savings over a reform with voluntary savings.

There are many other explanations for this finding, such as the lack of self-control and the fear of procrastination, the expected higher likelihood of government bail-out if a pension fund fails in which mandatory savings were invested, etc. All these arguments underscore a need for government intervention - most strongly, in the imposition of a mandatory saving plan; less strongly, by giving tax relief. Compromises are possible, such as thresholds up to which savings have to be made, and/or a thresholds up to which savings are subsidised.

\subsection{Risks and Public Policy}

The provision of old age insurance is the response of society to the risk faced by individuals of surviving to a given age without adequate resources to finance consumption. Indeed, the traditional argument in favour of public pension programmes is that annuity markets, tailored to insure against longevity risks, are often missing or underdeveloped. However many economic risks, beyond longevity risks, potentially affect retirement income provision. In fact, PAYG systems and most occupational pension and collective pension contracts automatically pool longevity risks as benefits are normally independent of individual's survival probabilities, hence longevity risks are well covered by these schemes and the attention is mostly shifted to other sources of uncertainty, particularly "macro" risks which cannot be pooled within a given pen- 
sion scheme or pensions system. One well known risk, usually associated with funded schemes, is the risk of reserve erosion and bankruptcy, possibly due to accelerating inflation . However, while large losses are associated with this risk, this is probably not the most worrisome, in terms of likelihood, for economies of the $21^{\text {st }}$ century: demographic risk and volatility in financial markets are currently discussed as causes for concern. We briefly describe the effects of these risks in turn.

One issue in the policy debate on pension reform and own saving for old-age recurs over and again: will there be more risk to be born by households in a world in which savings have to finance in the future what social security has provided in the past? Specifically, can history repeat itself and drive millions of elderly in poverty when asset prices collapse such as after the Great Depression? And even more threatening: Don't we know that asset prices will collapse when the baby boomers retire?

We will begin with the last question since we can provide a quantitative answer, based on our earlier computations for Germany. Departing from Figure 2.2 in subsection 2.1 and our estimate of one third crowding out in subsection 2.2, we compute the accumulated contributions to private pension accounts. They are depicted in Figure 2.3. It is based on the transition model described in subsection 2.1 and an assumed rate of return of $4.5 \%$. 
Figure 2.3: Accumulated Contributions to Private Pension Accounts, 2000-2050

(Billion DM, real)

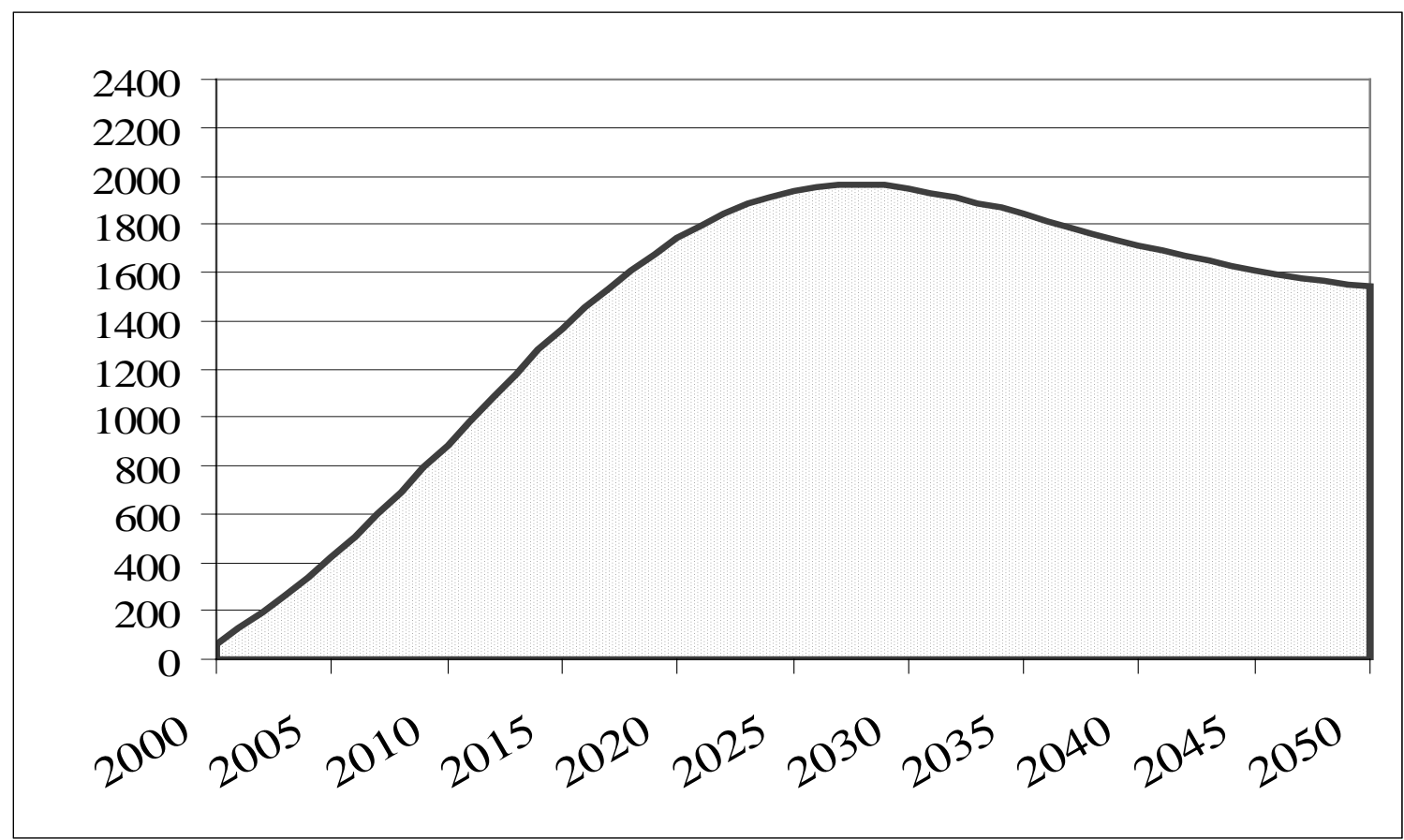

Note: The 1998 GDP in Germany was about 3750 billion DM. Source: Birg and Börsch-Supan (1999) and Börsch-Supan, Heiss and Winter (2001).

The path in Figure 2.3 has several implications. First, while the transition to more funding will generate substantial savings in order to provide for income in old-age, the magnitude of accumulated new savings will not create dramatic interest changes. The long run value (year 2050) represents about $10 \%$ of current gross fixed capital, and about $16 \%$ of gross fixed capital in the production sector. It is about equal to today's value of life insurance savings and occupational pensions. This implies that the effect on the rate of return is limited. Based on the OLGmodel already used a few times, we estimate a decline of 80 basis points if all capital is invested in Germany, and of less than 10 basis points if it is invested in the OECD in proportion to each country's GDP.

Second, the accumulation takes place slowly, echoing the freezing scenario. More significantly, there is no sudden decline in the capital stock around the year 2030 when the baby boomers retire. Main reason is that the baby boom retirement entry stretches about 10 years, during which the new pillar has not yet matured. The increase in new accounts therefore compensates for a substantial portion of dis-saving among the retired baby boomers. This also explains part of the small reaction of returns with respect to demographics. 
A much harder question is whether an increasing reliance on own saving for old-age provision will expose households in the future with more risk than today. This is a hard question because many different kinds of risks are involved. Inherent in PAYG systems are demographic and political risks, while the reliance on savings always carries capital market risks, among them inflation and exchange rate risks. The issue is complicated further because risk is to be distinguished from vulnerability. While risk (ex ante) is measured typically as the expected variance of the retirement income package, vulnerability can be expressed as the probability that the retirement income package will provide an income that will be at or below the subsistence level. If the heterogeneity of retirement income increases, it is the danger of increased vulnerability that - arguably - deserves most policy attention. This paper cannot discuss these issues in detail, and we refer to Börsch-Supan and Reil-Held (1998) for an extended review.

Demographic risks are associated with both PAYG and funded systems. The demographic risk of a PAYG system has been documented extensively (OECD, 1988; World Bank, 1994). While most demographic trends can roughly be foreseen, residual uncertainty remains. Most importantly, it is far from clear how pension policy will respond to the demographic changes. Thus, from an individual point of view, the consequences of demographic changes to her/his pension are uncertain. This can be expressed in the variance of predicted internal rates of return in PAYG systems. Funded pension systems also carry a demographic risk because capital will be abundant relative to labor when the ratio of workers in the total population declines. The corresponding decrease in the rate of return of capital, however, is much lower than in the PAYG case.

Political risks refer to the risk that claims on retirement income are altered by political action. In the case of funded pensions, funds may be used for purposes other than those originally designated, or, in the worst case, simply be appropriated as in some developing countries (Börsch-Supan, Palacios and Tumbarello, 1999). PAYG pension systems face the risk of legislative changes. German and Italian workers, for example, experienced a flurry of pension reforms since 1990, and further reforms are expected. While these reforms may address the demographic changes, they are superimposed by short-term considerations. The uncertainty facing individual workers with respect to their future PAYG pension claims has frequently been documented in polls and surveys.

Capital market risks are intrinsic to funded pension systems. They include variation in the real rate of return, the risk of inflation if future pension claims are expressed in nominal terms, and 
the risk of exchange rate fluctuations if claims are denominated in a different currency than consumption. It appears that the risk-return profile of the international capital market has unambiguously shifted. While the real rate of return of the three major OECD business sectors has changed from below 3 percent p.a. in the 1970s to well above 7 percent p.a., the risk, measured as coefficient of variation, has decreased (McKinsey Global Institute, 1994). This may be due to more experience with the "management" of capital markets and is reflected in the relative ease with which major crises such as the United States stock market crash in October 1987, the bubble burst in Japan 1990, and, more recently, the crises in Mexico and Asia have been absorbed in comparison to the far reaching consequences of the crises that occurred between World Wars I and II. Inflation risk will depend on future monetary policy, in Europe dominated by the developments within the European Monetary Union and the introduction of the Euro. Instruments such as inflation-indexed bonds will internalize the inflation risk that pensioners are exposed to within the government and the monetary authorities. While PAYG systems are exposed to demographic risk, they are immune against inflation risks because claims are typically indexed by wages and/or purchasing power.

The popular discussion in many European countries tends to overemphasize return risks in capital-market based funded systems, while it at the same time puts too little emphasis on the demographic and political risks of the PAYG system. In assessing the relative risks, it is often overlooked that investment risks can be diversified across countries while the risk intrinsic in the PAYG system cannot. It is also frequently overseen that risk has to be judged in connection with return. To take the example of the German PAYG system: it will provide an internal rate of return for a worker born in 1960 of approximately between - 0.5 percent to 0.5 percent, depending on the policy mix. In turn, the annual rate of return of corporate investment, based on a five-year moving average, has fluctuated between 4 and 16 percent in real terms between 1980 and 1995. If this pattern prevails, risk measured as variation in the rate of return is higher in the capital market, but the lowest return in the capital market still dominates the highest return of the PAYG system.

The risks for funds based on stocks and bonds are reasonably well understood. Less understood are the risks associated with investment in housing and in book reserves popular in some countries. The wealth of most households, notably in the middle class, is concentrated in the own family home. While housing wealth may serve as a shield against inflation, it is exposed to its own variant of "capital market risk" (in the sense that its price may fall relative to consump- 
tion) and a potentially large demographic risk (Mankiw and Weil, 1989; but see the discussion in Hendershott, 1991).

Shifting more retirement income from PAYG to funded provision will clearly increase capital market risk, but at the same time, it probably reduces the demographic and the political risk. The balance is unclear. Moreover, risks cannot be added or subtracted - it is the package and the correlation of its components that determine total risk. The added diversification of a mixed system is the most convincing argument that risk exposure may actually decline in the future, unlike to popular belief.

Managing the return risk of funded pensions on an individual level, however, requires in most countries of Continental Europe more experience. Households have to "experience" the force of compound interest to learn that starting too late with saving is very expensive and increases risk exposure. Techniques like shifting portfolios from risky to conservative during working life are not well-known, instruments with a dynamic portfolio cannot be bought easily.

This leads to the observation that even in the modern countries of Continental Europe there are still many underdeveloped or missing institutions and instruments. Some capital market instruments, such as instruments with dynamic portfolios or a guaranteed minimum return, are in the process of being created by the market as funded retirement income provision becomes more widespread. Some institutions may be missing because of market failures; and must therefore be created by the state, such as fair annuities, an equivalent to deposit insurance for pension funds, or inflation indexed bonds.

\section{Savings and the "New Financial Landscape" in Europe}

We have argued that pension reforms may imply a shift toward private provision for retirement and that, in turn, this requires well functioning financial markets. This section is devoted to the introduction of new financial products mainly through institutional investors which are directly related to population ageing. The first part picks up the discussion of Section 2 on the complex relationships among the reform of public pension provisions, the onset of private pension funds and the growth of capital markets. In the second part we touch briefly on the changes of mortgage arrangements and consumer credit availability, which may contribute to create a different choice set for savings of the next generations. The interactions between changes in household saving behaviour and developments of markets obviously work in both directions. 
Continental Europe portrays a financial landscape that is quite different from the Anglo-Saxon countries. In particular, stock market capitalisation in the large Continental European countries, while dramatically higher than just a few years ago due to the bull market (France: 104.8\%; Germany: 67,8\%; Italy: 62.7\%) is still much smaller than in the Anglo-Saxon countries (UK: 200.7\%, US: 181.1\%), the Netherlands (192.2\%) and Switzerland (269.3\%; all figures for end of 1999).

This picture, however, may display a landscape that will soon be a matter of the past. Europe has witnessed important changes in credit and financial markets. The growth of institutional investors, visible in Table 3.1, and the liberalisation of markets - coupled with the advent of the EMU (European Monetary Union) - has been often referred to as a new engine for growth in European capital markets.

Table 3.1 Average Annual Growth Rate of Assets Held by Institutional Investors in Selected Countries, in percentage (1990-1995)

\begin{tabular}{|l|c|c|c|c|}
\hline Country & $\begin{array}{c}\text { Insurance } \\
\text { Companies }\end{array}$ & $\begin{array}{c}\text { Pension } \\
\text { Funds }\end{array}$ & $\begin{array}{c}\text { Investment } \\
\text { Companies }\end{array}$ & $\begin{array}{c}\text { All Inves- } \\
\text { tors }\end{array}$ \\
\hline Canada & 3 & 6 & 29 & 8 \\
\hline France & 19 & 19 & 8 & 13 \\
\hline Germany & 11 & 5 & 22 & 13 \\
\hline Italy & 9 & 3 & 14 & 9 \\
\hline UK & 10 & 6 & 14 & 9 \\
\hline US & 8 & 10 & 19 & 11 \\
\hline Europe (20) & 11.4 & 6.8 & 16.5 & 11.3 \\
\hline & & & & \\
\hline
\end{tabular}

The channels through which developments of financial markets, and in particular the advent of institutional investors take place are determined by demand conditions and features of the supply of financial services ${ }^{15}$. We discussed at length one potential demand factor due to ageing: one scenario is that the advent of pension funds should prompt "thick market externalities", i.e. positive externalities which, also because of economies of scale, reduce transaction costs and

\footnotetext{
${ }^{15}$ Introduction to institutional investors and institutional investing, Blommestein and Funke (1998).
} 
increase the willingness to invest in risky assets ${ }^{16}$. Technological progress in the processing and dissemination of information, which reduces the costs of providing complex financial products and facilitates deregulation of the banking and insurance industry - resulting in increased competition and growth of the market - in turn speeds up technological progress. This process could be further accelerated by European financial integration.

Indeed, ageing is not the only secular change that affects saving. Europe has also experienced significant changes in credit markets that are the result of deregulation processes and of specific EC directives (particularly felt in credit and mortgage markets).

The third secular change for Europe is the rapid financial and monetary integration. Since this integration imposes the law of one price for all financial products in Europe, differential taxation among member countries have many side-effects. We will only briefly touch at this discussion in the third subsection.

\subsection{The role of pension funds in Continental Europe}

Growth of total assets held by pension funds gives a measure of their growing importance, see Table 3.2. In Europe, overall, total assets of pension funds have grown at an annual growth rate (between 1990 and 1996) of $9.6 \%$ as opposed to a growth of $12.1 \%$ in North America. Furthermore, while private pensions and other forms of income from capital account for up to $70 \%$ of household income for older households of the higher income group (60\% in Canada and in the UK), these are negligible in Italy and account for $20 \%$ of total income in Germany. Net social transfers (inclusive of public pensions) account for more than $90 \%$ of resources in the low income group in Italy ${ }^{17}$. Overall, pension funds are still underdeveloped in Europe as opposed to North America and even "rich" people still shun from this type of investments. ${ }^{18}$

\footnotetext{
${ }^{16}$ Pagano (1993) provides a theoretical model to explain this mechanism. The onset of pension funds and pension-related financial instruments may also lead to qualitative changes in supply, by stimulating the creation of new products or even prompting a deregulation process (Davies, 1998)

17 Source: OECD (2000a). On the one hand these numbers simply confirm the relative importance of the different pillars in different countries as stressed in table 1, on the other hand these highlight the main sources of retirement income by income groups.

${ }^{18}$ This overall impression is valid in spite of many measurement issues and a lack of unified accounting rules even within the EU. In many countries, only defined contribution (DC) plans enter the definition of private wealth while defined benefit (DB) plans do not, rendering cross national comparisons difficult. Harmonisation of accounting rules is debated (see EC 1999) but a major worry of pension funds is that tight accounting rules (e.g. on indexation) may interfere with flexibility of choices and performance of the fund.
} 


\begin{tabular}{|l|c|c|c|}
\hline Table 3. & \multicolumn{3}{|c}{ Financial } \\
\hline Country & $\mathbf{1 9 9 0}$ & $\mathbf{1 9 9 7} / \mathbf{1 9 9 8}$ \\
\hline Austria & 0.0 & 2.6 \\
\hline Belgium & 2.0 & 4.8 \\
\hline Canada & 28.8 & 47.7 \\
\hline Denmark & 14.6 & 21.5 \\
\hline Germany & 3.1 & 3.3 \\
\hline Italy & 3.5 & 3.2 \\
\hline Netherlands & 81.0 & 85.6 \\
\hline Norway & 4.4 & 7.2 \\
\hline Portugal & 1.6 & 12.0 \\
\hline Spain & 2.9 & 2.1 \\
\hline Sweden & 1.7 & 2.7 \\
\hline UK & 55.0 & 83.7 \\
\hline US & 44.9 & 86.4 \\
\hline Source: OECD (2000a) Table 6.1 & \\
\hline
\end{tabular}

What is clear is that most people in Continental Europe are not used to stocks or stock-related funds. There is, however, a strong increase recently in the share of stocks in household portfolios, see Eymann and Börsch-Supan (2001) for Germany; Alessie, Hochguertel and van Soest (2001) for the Netherlands. This tendency has large potential benefits, but also carries risks that might requires policy attention.

We have already mentioned the potential technical benefits to the financial system and to economic growth, mainly through "thick market externalities" and information processing. Whether there are additional economic benefits through improved corporate governance is hotly debated. Börsch-Supan and Winter (1999) collect pieces of evidence that link the share of assets managed by institutional investors (mainly pension funds) with improved capital productivity. France, Germany and Italy with a low share of institutional investors do indeed have a significantly lower capital and total factor productivity, but the causal link is tenuous at this point. The link is important since small changes in productivity have a lasting effect on GDP per capita. Börsch-Supan, Heiss and Winter (2001) show that a lasting increase of total factor productivity by just 0.2 percentage points suffices to offsets the transition burden to the partially funded pension system described in Section 2. 
While the benefits of institutionalized financial markets may take time to emerge, a crucial and urgent policy issue is the information of citizens about the chances and dangers of investing into the stock market. A recent OECD report also warns against advertising pension funds as "the solution" to ensure income in retirement and as a market success. ${ }^{19}$ Safe investment of saving for retirement in private funds requires well-functioning capital markets and an appropriate regulatory framework. The features that pension funds should display and the rules they should satisfy are discussed at length in several document ${ }^{20}$ and we are not taking them up in this survey, however a number of important issues, arising specifically in some countries, should be mentioned.

First, the lack of information has been documented extensively; and the UK mis-selling experience, already mentioned in Section 2.3, has shown the risks involved in a partial transition that is not accompanied by government regulations on disclosure, information, and the possibility to revoke contracts within a given period of time. In addition, public education in schools on these issues is practically non-existent.

Second, supervision of fund performance and information to investors occupy an entire chapter of pension funds and life insurance business regulation and are referred to as "transparency" rules. Also, it has been argued that changes to old age insurance arrangements may be at times too radical and too fast for consumers and the financial sector to adjust. In these cases implementation of new directives may lead to abrupt changes and portfolio reshuffles resulting in instability of capital markets ${ }^{21}$.

Finally, the importance of encouraging competition in the pension industry (or even of encouraging direct participation into equity markets as in the U.S.) or the need to apply the prudent man principle on an global environment, rather than adopting home-biased pension investment policies, are the two issues often discussed in relation to the return-risk trade off characterising the choices by pension fund managers.

\footnotetext{
${ }^{19}$ OECD (2000a).

${ }^{20}$ See OECD (2000a), EC (1999) for examples. The most salient features of European pension funds can be found in Davies (1995) and Laboul (1998).

${ }^{21}$ OECD (2000a) discusses Sweden as an example of possible undesired side-effects.
} 


\subsection{Financial Liberalisation and the Changing Role of Formal and Informal Credit}

\section{Markets}

The financial liberalisation experienced in Europe throughout the recent decade has, by and large, lifted existing credit restrictions (e.g. in housing markets, see Chiuri and Jappelli, 2000). It is not obvious how this will affect aggregate saving. If consumers were "saving too much" in a life cycle sense, because of liquidity constraints, there might be a negative effect on saving due to the introduction of new financial products ${ }^{22}$. However, more frequently credit restrictions apply to the purchase of durables, hence increased access to credit may simply encourage durables purchases and, under certain conditions, this may be viewed as substituting forced liquid savings for durable goods purchases. Which effect will prevail? The following subsection looks at this question more closely.

Households may need to borrow during their lifetime. The standard life-cycle motive is that young households borrow in order to smooth consumption (i.e. to finance current consumption) in view of increasing age-earnings profiles, more generally households may save in order to maintain a given target of the ratio wealth to income or as a buffer. Increased credit availability may reduce savings as the result of removing a liquidity constraint. House purchases and durable-goods purchases are a common reason for starting up a mortgage or a consumer loan or to sign consumer purchase agreements. Home buyers, who prefer owning to renting, are often faced by the problem of building up a down-payment, because mortgages finance only a fraction of the cost of the property. The higher the down-payment the stronger the effort for young households to accumulate capital in order to meet the payment at the time of purchase: a mechanism akin to liquidity constraints. Obviously, in economies where downpayments are reduced due to a developed mortgage market, liquidity constraints are less severe and the saving rate may be low as a result. Similarly, access to new consumer credit facilities softens the effects of constraints on durable goods purchases.

According to the way in which credit markets and mortgage markets solve problems of informational asymmetries, market imperfections may take different forms. In perfectly functioning markets consumers can borrow and lend the desired amounts at the prevailing interest rate. An extreme form of market failure takes place when asset or insurance markets are completely

\footnotetext{
${ }^{22}$ As argued in Hayashi (1987), the existence of future expected liquidity constraints may also induce suboptimal behaviour in a life cycle sense ("too much" saving). Future constraints may be important for young
} 
missing or very thin (see annuity markets in Europe). However it is more common to observe imperfect credit and mortgage markets where some rationing takes place or where interest rates are characterised by a wedge (spread) between the borrowing rate and the prevailing market rate.

In order to document the importance of credit and mortgage availability and to describe the variety of arrangements existing in different countries, Table 3.4 presents, as an example, some characteristics of mortgage markets ${ }^{23}$. Credit conditions for homebuyers are converging throughout Europe to a more competitive environment, this should encourage home purchases and allow young households easier access to the mortgage market.

Table 3.4 Housing Finance Arrangements for Selected Countries

\begin{tabular}{|c|c|c|c|c|}
\hline Country & $\begin{array}{c}\text { Outstand- } \\
\text { ing Mort- } \\
\text { gage }\end{array}$ & $\begin{array}{c}\text { Interest } \\
\text { rate } \\
\text { spread }\end{array}$ & & Downpayment ratio \\
\hline Austria &.. & 1.52 & 40 & 20 \\
\hline Belgium & 20.08 & 1.02 & 35 & 20 \\
\hline Canada & 44.00 &.. & 25 & 20 \\
\hline Finland & 32.35 & 1.23 & 20 & 20 \\
\hline France & 22.05 & 0.95 & 20 & 20 \\
\hline Germany & 45.11 & 1.10 & 35 & 20 \\
\hline Italy & 5.30 & 1.47 & 50 & 40 \\
\hline Netherlands & 43.29 & 0.41 & 25 & 25 \\
\hline Spain & 15.01 & -2.30 & 40 & 20 \\
\hline Sweden & 45.00 & 0.20 & 10 & 25 \\
\hline UK & 51.87 & 1.08 & 19 & 5 \\
\hline USA & 45.00 & 1.60 & 20 & 20 \\
\hline & & & & \\
\hline
\end{tabular}

Source: Chiuri and Jappelli (2000)

Indirect evidence of the extent to which imperfect mortgage markets may affect home purchases (and related saving decisions) can be obtained by considering data on co-residence. While there are several potential explanations for the existence of extended families (i.e. more 
than one nuclear family living in the same household) or for co-residence of adult (often working) children with their parent(s), there is a strong presumption that imperfections in the mortgage market is a determinant factor for living arrangements.

Table 3.5 Proportion of young adults living with parent(s)

\begin{tabular}{|c|c|c|c|c|}
\hline Country & $\begin{array}{c}\text { Male aged } \\
\mathbf{2 5 - 2 9}\end{array}$ & $\begin{array}{c}\text { Female } \\
\text { aged 25-29 }\end{array}$ & $\begin{array}{c}\text { Male aged } \\
\mathbf{3 0 - 3 4}\end{array}$ & $\begin{array}{c}\text { Female } \\
\text { aged 30-34 }\end{array}$ \\
\hline Canada & 26 & 14 & 11 & 6 \\
\hline Finland & 0 & 4 & 0 & 2 \\
\hline Germany & 32 & 12 & 14 & 3.5 \\
\hline Italy & 76 & 50 & 32 & 19.5 \\
\hline Japan & 59 & 48 & 37 & 28 \\
\hline Netherlands & 27 & 6 & 6 & 1.5 \\
\hline UK & 21 & 9.5 & 65 & 4 \\
\hline USA & 19 & 12 & 8 & 5.5 \\
\hline
\end{tabular}

Source: OECD (2000a). Calculations based on the Luxembourg Income Study and national census data.

Both for Italy and Japan there is a remarkable high percentage of young adults (particularly men) living with their parents. This correlates with mortgage market variables. Co-residence is only one example of the possible effects that household composition and demographic changes have on household saving behaviour, the presence and the cost of young children is another example where important effects have been found. ${ }^{24}$

The empirical implications of the variety of arrangements and the severity of the constraints are complex ${ }^{25}$. In countries where the required down-payment is low the saving rate tends to be low. ${ }^{26}$ The down-payment may affect the homeownership decision and the timing of purchase, the higher the down-payment the smaller the probability of an household making a purchase and the longer the waiting period before the purchase takes place. Given the age structure ex-

\footnotetext{
${ }^{24}$ See the review by Banks and Tanner (1999).

${ }^{25}$ Jappelli and Pistaferri (2000) discuss these points which would deserve an entire section on their own right.

${ }^{26}$ This is shown by Jappelli and Pagano (1994). In particular they show that in periods where the downpayment in Finland, Sweden, Ireland and the UK was signficantly lower than in other countries (i.e. during the 1970s), the saving rate was also significant lower. Further evidence on this can be found in Chiuri and Jappelli (2000).
} 
isting in a given economy and the propensity to save of different cohorts, this may have sizeable and conflicting effects on aggregate saving. For example, Hayashi et al. (1988) argue, on the basis of a simulation exercise, that an increase of 20 percentage points in the downpayment in the US economy would lead to an increase of 1 percentage point in the saving rate, while a more substantial increase may lead to a reduction in saving rates due to an increase in the number of discouraged buyers.

Note that the same arguments based on constrained consumers can be put forward for other durable goods and, although the stock value of durable goods may be considerably smaller than the stock value of homes in the economy, consumer durables represent an important part of the personal sector and of households' budgets. Hence the amount of saving earmarked for future durable purchases may be non negligible. There is a growing body of literature on the importance of liquidity constraints in limiting the purchase of durable goods and, more generally, in affecting the decision between durables and non-durables consumption (particularly cars). This is relevant for saving behaviour not only because higher current consumption corresponds to lower saving, but mainly because increased credit availability may be earmarked to durable purchases. Hence, new financial products, when lifting credit constraints, may greatly affect the relationship between saving and durables consumption while leaving almost unaffected non-durables consumption. For example Brugiavini and Weber (1994) show, on Italian cross-sectional data, that liquidity constrained households purchase fewer cars than unconstrained households, but this outcome strongly depends on the age of the head of the household (younger households enjoy more favourable credit limits) ${ }^{27}$.

Finally, both for home purchases and for credit provision in general, an important role is played in Europe by "informal markets": it is often maintained that households and families substitute for missing credit or insurance markets ${ }^{28}$. Intergenerational transfers (whether truly altruistic or strategically motivated) could partly explain differences in saving behaviour across countries as well as differences in the age-saving profile. What is relevant in this context is that some inter vivos transfers or bequests take place within the household or between related households (from parents to children) to compensate for the existence of various forms of liquidity constraints. For example, it is estimated that in Italy more than a third of homeowners obtained the

\footnotetext{
${ }^{27}$ See also Alessie, Devereux and Weber (1997).

${ }^{28}$ See the seminal paper by Kotlikoff and Spivak (1981).
} 
property directly as a gift or bequests from relatives or received financial support for the purchase (Guiso and Jappelli, 2000). However, inter vivos transfers earmarked to house purchases are not a relevant portion of the property price, hence mortgage market imperfections are confirmed as important explanations of the high aggregate saving rate observed in Italy. More generally, while informal markets may limit the welfare costs of credit restrictions, as shown by the fact that transfers are usually in favour of liquidity constrained households (Guiso and Jappelli, 1994), these cannot substitute for well-developed credit and insurance markets and cannot guarantee that constrained households will eventually implement their optimal consumption plan. ${ }^{29}$

It is hard to draw a conclusion on whether changes in credit markets have a sizeable impact on saving, the existence of informal markets may further contribute to blurring the picture. The empirical work is faced with the difficulty of carefully describing market arrangements and pinpointing, amongst the several key aspects affecting saving decisions, the effects directly related to improved market conditions. An example of these difficulties is summarised in Banks and Tanner (1999) who review the debate concerning the fall in saving experienced during the late 1980s in the UK. While Muellbauer and Murphy (1990) argue that this is due to the consumption boom following the euphoria of rising housing prices and relaxed credit arrangements (hence a direct consequence of housing market distortions coupled with improved credit availability), Attanasio and Weber (1994) argue that the growth in consumption experienced by UK households is simply the result of permanent changes in lifetime resources of younger cohorts. In the latter case changes in saving behaviour are not directly linked to changes in credit markets.

\subsection{European integration}

Two important aspects of the institutional and regulatory framework which interact with the features of new financial landscape are: the tax treatment of different assets, which is one major point in the debate over the "single market for Europe", and the advent of the single currency (EMU). The differential tax treatment of financial products may encourage or discourage the demand for specific assets and create "privileged saving", in particular different tax treatment across member states may produce, on the one hand, distortions which are reflected

\footnotetext{
${ }^{29}$ See Ando, Guiso and Visco (1994) and the papers quoted therein.
} 
in different saving and portfolio holding patterns in different states and, on the other hand, it may create barriers in the flow of capital between states. This discussion of a "level playing fields" is a heated debate in Europe, and a central link between public policy and saving. This is not the paper to discuss capital taxation at length (see the Green Paper by the European Commission, 1999, and Blommestein and Funke, 1998), as it would also call for a treatment of the different legal systems in terms of contract enforcing and the different labour market arrangements. However one aspect can be singled out as the possibility for member states to achieve better coordination, if not harmonisation, and this rests on the taxation rules applied to pension funds. The adoption of the EET (exempt-exempt-taxed) rule as opposed to other rules for taxing the contribution into the scheme, the capital or the benefit emerging from the scheme, may be a basic requirement to avoid double taxation problems and free movements of capital and workers between states ${ }^{30}$. If these fail the effects of pension funds on macroeconomic performance and on saving may be much reduced.

The onset of the EMU is also associated with financial development, and in particular with an increasing role for securities markets as opposed to traditional banking, as well as important changes in corporate governance and corporate control. The underlying economic mechanism is the reduced transaction costs and increased economies of scale (see also section 3.1), which should follow the onset of the single currency and should hence allow for greater competition in the financial sector. This is due, besides the elimination of the exchange rate related costs and exchange rate risk, to a reduction in the overall risk (or perception of risks, e.g. inflation risk) a better synchronisation in the timing of financial contracts and a widespread restructuring of the European financial sector. Eventually, only differences in preferences by investors should explain possible country-specific financial market segmentation, while the scope for diversification and risk pooling across countries should be much increased ${ }^{31}$.

The introduction of the single currency should also reduce transaction costs across member states, hence favouring cross border investments and reducing the home-bias in portfolios of individual investors and institutional investors. As a result financial markets and financial institutions should be more competitive and offer a wider set of better products.

\footnotetext{
${ }^{30}$ This view is not uncontroversial, see Dilnot et al. (1994) for a discussion.

${ }^{31}$ Davies (1998) discusses these points in detail.
} 
Financial integration is also an important aspect in an ageing Europe. As we argued earlier, ageing will necessitate a much larger share of funded pensions than we currently have. If these funds are invested nationally only, returns will remain dependent on national demographics. The integration of financial markets, however, permits "gains from trade" when capital flows from faster to slower ageing countries, improving the welfare of both county groups (BörschSupan, 1996). Reducing or even eliminating exchange rate risks and introducing common and transparent disclosure rules help exploiting these gains.

The ultimate effect of these different developments on household saving is not easily assessed. The commonly held view is that, due to the existence of new products consumers may enter directly capital markets (e.g. become share holders) and this may increase savings or substitute for existing saving or that consumers may enter capital markets indirectly through institutional investors. The latter may again be "new capital accumulation" or substitute for existing assets. Whichever the effect on total saving, the composition of saving has remarkably changed through the growth in institutional investors in Europe in recent years.

\section{Savings Now and in the Future: Too Little or Too Much?}

Public policy has always cared about the volume of saving. Some argue that saving rates are too low - hence, saving needs to be incensed by tax relief. Particularly U.S. economists are worried about the low - some argue, even negative - saving rates in the U.S. Excessively low saving rates dampen capital accumulation and reduce economic growth. In turn, some European economists argue that European saving rates are too high. Excessively high saving rates dampen consumption demand and may reduce economic growth, e.g. in Keynesian models characterised by frictions and rigidities.

But what is "excessive"? The first subsection will briefly look at today's saving rates with this question in mind. It will be brief since we have little evidence on this complicated question. The second subsection poses an easier question: how will saving rates evolve in the future. Specifically, how will they react to population ageing? Are capital shortages in the wake of population ageing a myth or a likely reality? ${ }^{32}$

\footnotetext{
${ }^{32}$ OECD (1996).
} 


\subsection{Today's saving rate}

Household saving rates in Continental Europe are much higher than in the United States, see table 4.1. Although the saving rates have declined in many countries, there is much less of a debate whether there is too little saving in Europe than in the U.S. In Germany, household saving rates have declined from $15 \%$ to some $12 \%$ in the wake of the unification tax hikes. The household saving rate also declined in Italy, and it is hard to find a one-dimensional explanation. The emergence of formal credit and mortgage markets, discussed in the previous section, drove the need for large down payments down, hence reduced saving. In addition, the decline in the share of composite households may have contributed to the decline in household saving.

\section{Table 4.1: Household Saving Rates}

\begin{tabular}{cccccccc}
\hline $\mathbf{D}$ & $\mathbf{F}$ & $\mathbf{I}$ & $\mathbf{E}$ & $\mathbf{G B}$ & $\mathbf{C H}$ & $\mathbf{J}$ & $\mathbf{U S}$ \\
\hline $8.6 \%$ & $15.7 \%$ & $12.7 \%$ & $10.2 \%$ & $6.2 \%$ & $8.1 \%$ & $13.1 \%$ & $2.4 \%$ \\
\hline
\end{tabular}

Notes: Figures refer to 1999. Sources: OECD (2000b).

There are some systematic reasons why saving may be too low. The microeconomic reasons are related to the basic task of saving: provision for future consumption. If people are myopic or underestimate future risks, saving will be too low. Paternalistic arguments then generate the demand for saving subsidies. The argument is asymmetric: it is more likely that individuals are myopic than too farsighted. Hence, economists tend to favour some tax-relief for saving, worrying about a lack of capital accumulation and growth. There is a growing literature that tries to measure the extent of myopia based on survey data and experiments. However, it is still an area of research in its infancy, see Kotlikoff, Spivak and Summers (1982) and Hamermesh (1982) for early contributions and the recent work on "hyperbolic discounting" for an approach which deals with saving decisions which are apparently equivalent to myopic behaviour (Laibson, Repetto and Tobacman, 1998). From a macroeconomic point of view, the "correct" saving rate can be inferred from the theory of optimal growth. This theory, however, yields little direct empirical guidance. Indirectly, we know that if the rate of return to capital is significantly lower than the "natural growth rate" of the labour force including its productivity gains, saving is too high; in this case, economists speak about a "dynamically inefficient" economy. Abel et al. (1989) have tried to compare appropriate rates of return with natural growth rates. According to their results, it is much more likely that saving is too low than too high; 
there appears little evidence that the economies in Europe (and the U.S.) are dynamically inefficient.

Whether saving is too low or too high has considerable political significance over and above the questions of investment and capital accumulation. If an economy has too high saving rates, PAYG pension systems are welfare superior to funded systems. In a dynamically efficient economy, it is the other way around. ${ }^{33}$ Hence, the elusive discussion about dynamic efficiency actually has a very concrete policy implication.

\subsection{Ageing and the saving rate}

How will the dramatic changes in the age structure of the European countries affect saving and investment? Will there be capital shortages? Will policy have to intervene?

There are many mechanisms that link saving with the demographic structure of a country. From a microeconomic point of view, saving rates vary by age - hence, a shift in the demographic composition of a country alters the aggregate saving rate even if the economic behaviour of each individual remains unaffected by population ageing. In addition, ageing may also change behaviour, i.e., age-specific saving rates, not the least through changes in the pension system as discussed in Section 2. In addition, there are macroeconomic feedback effects, for instance through changes in the rate of return to capital.

We first look at the pure composition effect. Departing from the textbook life-cycle model (Modigliani and Brumberg, 1954) and its implied dissaving in old-age, one might expect a severe decline in the aggregate saving rate in response to population ageing. We show, using actual life-cycle profiles of saving, that this conclusion is premature.

We then model the behavioural responses of age-specific saving rates to population ageing. This is a much harder exercise since it necessitates a quantifiable model of saving behaviour. As it turns out, the results of the two approaches are contradictory. In a third section, we therefore interpret the discrepancies and speculate on the likely "true" projection.

\footnotetext{
${ }^{33}$ The reader is reminded that this reasoning applies to de novo systems and that transition costs complicate the welfare comparison. Much of the pension reform discussion in Section 2 actually presupposed that there is not already too much saving in the economy.
} 


\section{a. Composition effects of population ageing on saving}

We first explore how aggregate saving rates will change during population ageing given what we know about current saving behaviour. The methodology is simple, see Börsch-Supan (1996): We classify saving rate, household income and household size by age and cohort, using the methodology described in Brugiavini and Weber (2001), then apply these age and cohort specific measures to projected population ageing and income growth ("shift-share analysis"). Projections of aggregate saving on the basis of a current description of behaviour is of course strongly subject to the Lucas-critique about the feedback of public policy on behaviour. Specifically, the stability of age-saving profiles throughout the ageing process is a strong assumption because pension provisions and transfer habits may be adapted in the wake of population ageing when relative cohort sizes change. This the topic of the next part of this subsection. Figure 4.1 shows age profiles of saving rates for Germany, Italy, Japan, the Netherlands, the UK and the US. They have, to put it mildly, only a scant resemblance with the predictions from the textbook life-cycle model. Most significantly, there is very little dis-saving observable in the data. The cohort-effect corrected profiles are different in several crucial dimensions from those employed in earlier IMF and OECD studies who used theoretical profiles based on the lifecycle hypothesis. We will see that the differences among these age-saving profiles have significant implications for long-term saving projections. 


\section{Figure 4.1 Household saving rates by age}

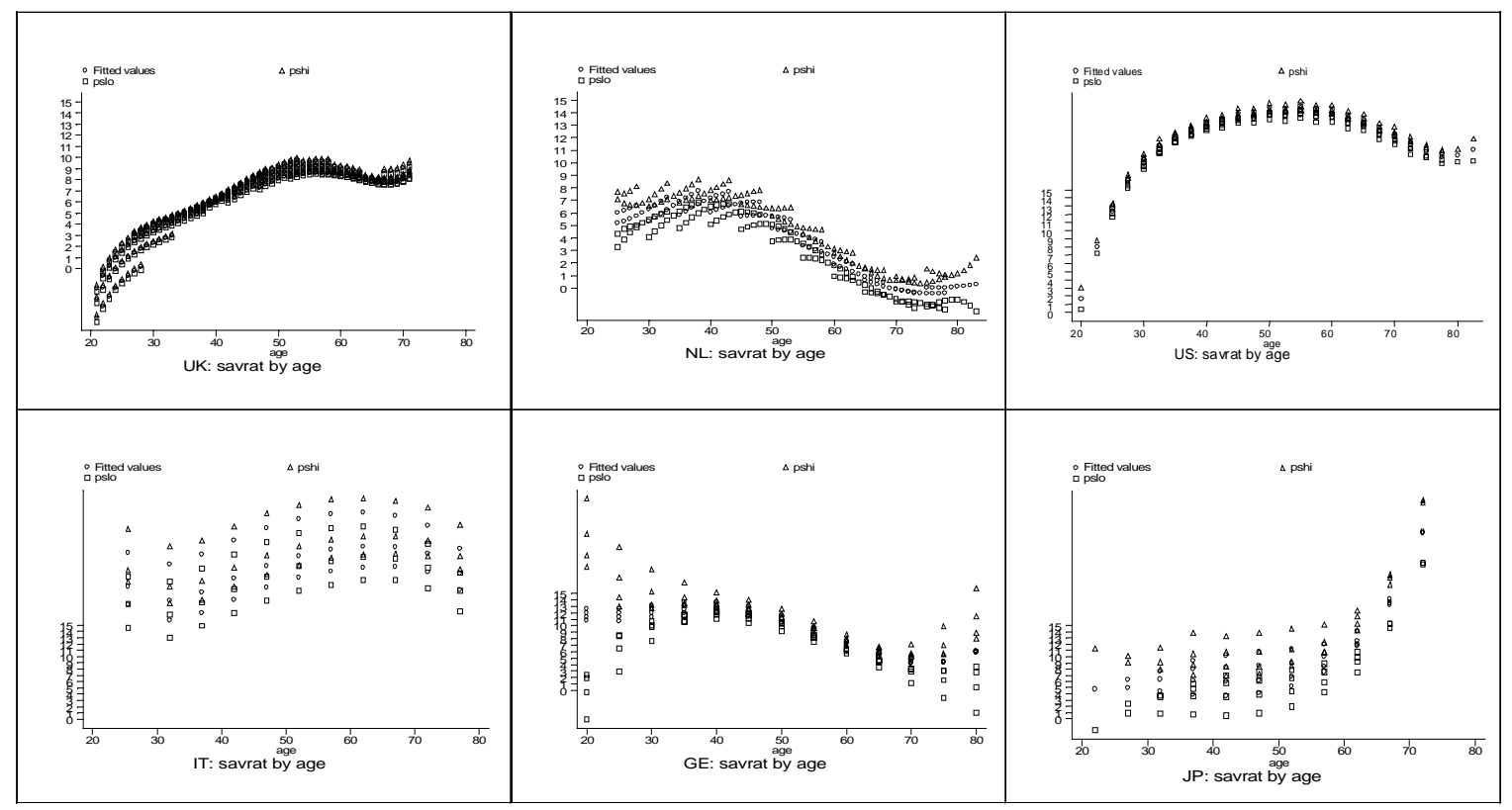

Source: Börsch-Supan (2001a)

For the purpose of projecting future savings, the high saving rates among households aged 4564 are significant because the baby boom generation will enter these ages soon, and because income is highest during those ages. The decline after age 65 , which is stronger in the cohortcorrected data than in the raw data, is an interesting puzzle in itself (e.g., see Banks, Blundell and Tanner, 2000; Börsch-Supan, 2001b), however, for a projection of total saving it turns out to be less significant because the population weights decrease with age due to mortality and because retirement income is lower than income at age 45-64.

Composition effects affect the aggregate saving rate quite differently in Continental Europe (represented in the computation below by Germany), North America (represented by the U.S.) and the industrialised economies in Asia (represented by Japan) because the underlying agespecific saving rates and speed and extent of population ageing are different across countries. In the United States, population ageing during the next 15 years shifts more weight to the high saving ages 45-64. After 2010, the numerous baby boom generation enters the low saving ages $65+$. Hence, as visible in Figure 4.2, American saving rates increase by 0.5 percentage points from 1990 to 2010, then fall almost to the 1990 level during the following 10 years. In Japan, saving rates increase almost monotonously with age, such that the effect of population ageing is similarly monotonous. Population ageing puts fewer households in the low saving age categories and more households in the high saving age categories, resulting in higher 
saving on an aggregate level. Japanese saving rates are projected to increase from 14.3 percent to 15.8 percent during the period considered.

In Germany, the overall effect is ambiguous. Population ageing reduces the relative proportion of households below age 37, but it also increases the number of households in the ,saving trough" after retirement. The increase in saving rates after age 75 is of smaller relevance because the number of households of very old age is relatively small even after taking account of the projected decline in mortality. As a result, the aggregate household saving rate in Germany - and, since the demographic changes are roughly alike, probably in all of Continental Europe - is almost unaffected by the population ageing process through 2020.

\section{FIGURE 4.2: Age-Composition Effect in OECD Saving Rates}

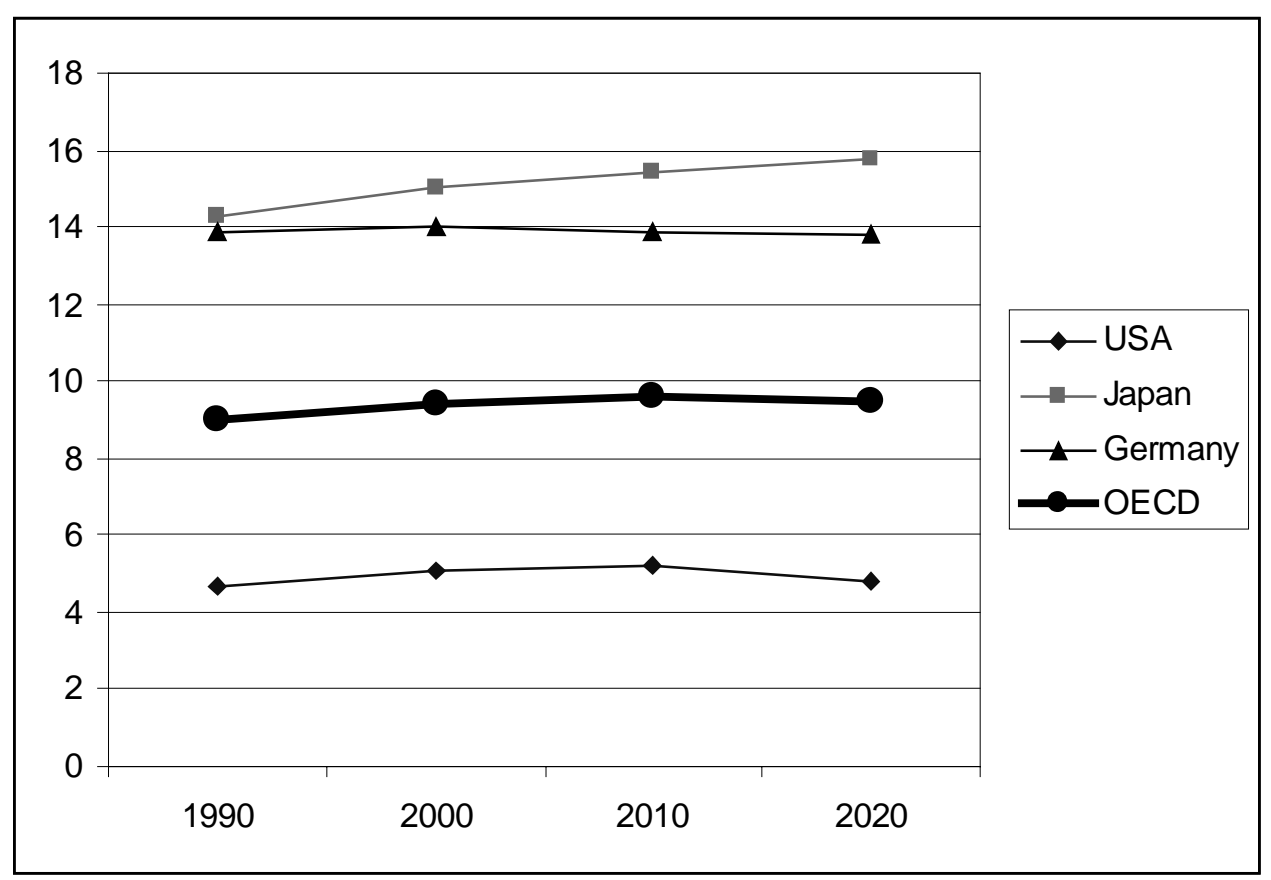

Source: Börsch-Supan (1996)

The results in Figure 4.2 are in sharp contrast to the projections by Heller (1989), Auerbach and Kotlikoff (1987), and Auerbach et al. (1989) which rest on the textbook life-cycle profile of saving rates. Our results rest on the combination of high saving rates and high incomes of the baby boom generation in the year 2010. In 1990, the leading edge of the U.S. baby boom generation was age 44, while the youngest baby boomers were 27 years old. In 2010, the baby boomers are between age 47 and 64, exactly in their peak saving and peak income ages. 


\section{b. Feedback effects of population ageing on saving}

The exercise so far is illuminating as it shows how misleading the naive projections from textbook economics can be. Actual behaviour is much more complicated than predicted textbook behaviour, leading to very different projections in the aggregate.

On the other hand, the above composition analysis is based on the flawed assumption that individual behaviour remains constant. In fact, there are many feedback effects that are likely to change individual behaviour, both directly and via public policy.

From a macroeconomic point of view, population ageing changes the current balance between output and labour such that there will be less workers per consumer than today. This will drive wages up relative to the remuneration of other factors of production, such as capital, reducing the incentive to save if the interest-elasticity of saving were positive. In addition, some capital may become obsolete due to the shrinkage of the labour force and diminishing returns to scale which worsens the declining attractiveness of accumulating capital.

While there is little debate about the validity of these basic mechanisms per se, their quantification is controversial. This section therefore explores the quantitative relevance of the various channels. We use a multi-country general equilibrium model, see Börsch-Supan (1995) and Birg and Börsch-Supan (1999), in which a global rate of return equilibrates the demand for, and the supply of, funds. It is based on a Cass-Ramsey-Solow optimal growth model in a version popularised by Cutler, Poterba, Sheiner and Summers (1990). The macroeconomic feedback of population ageing on saving behaviour can be interpreted as a prediction of the future cohort effects mentioned in the first part of this subsection.

The main result is shown in Figure 4.3. In a forward looking general equilibrium setting, per capita consumption will decline, but so does saving and investment, mainly, because a rising capital labour ratio due to population ageing will depress the return to capital in the ageing Continental European countries. As a result, the path of saving follows closely the path of labour force growth. Until the year 2010, the aggregate saving rate pretty much remains at the 1990 level. After 2010, the saving rate declines by about 2 percentage points when population ageing speeds up and reaches its minimum in the year 2035, ten years after the greatest decline in the labour force. 
Figure 4.3: Aggregate Saving Rate

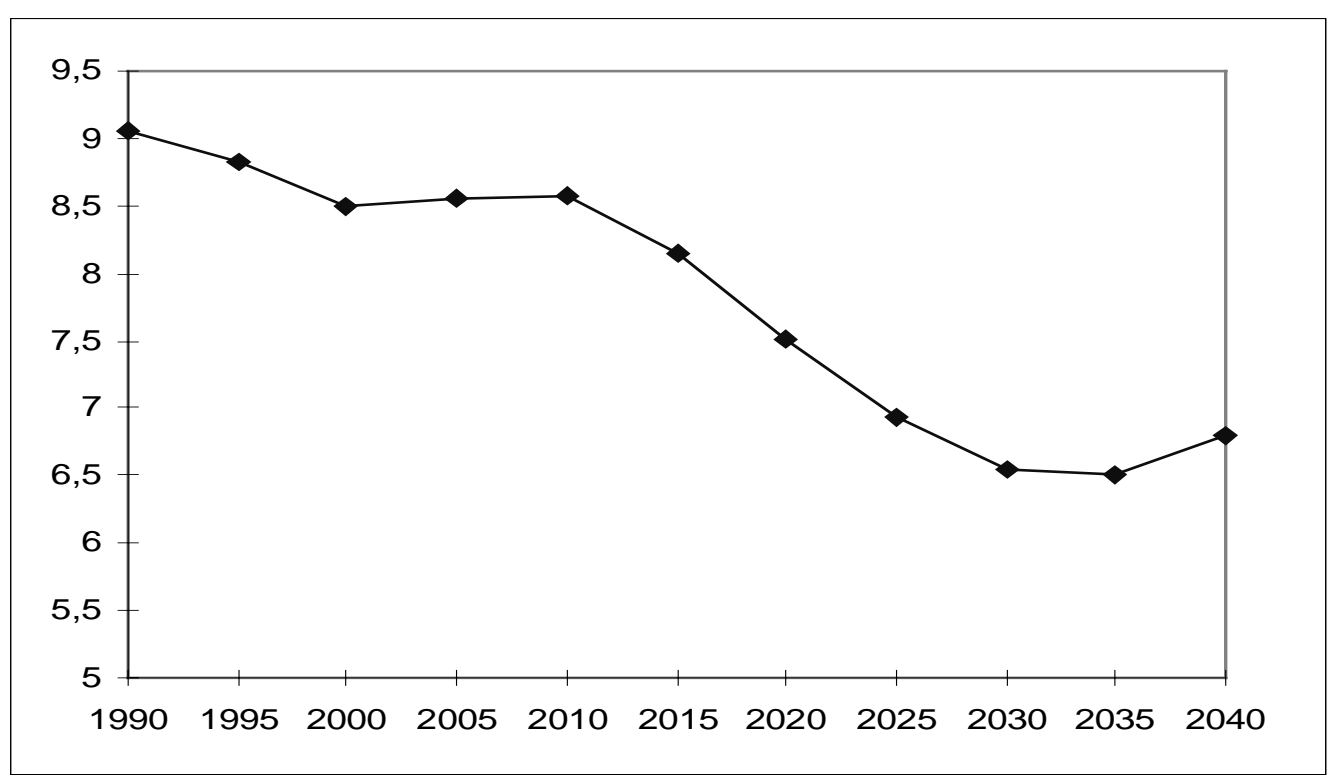

Note: Aggregate OECD net household saving rate. Source: Börsch-Supan (1996).

Figure 4.3 is based on the assumption that all savings are invested nationally. The decline of the savings rate is smaller when international capital flows reduce the decline in the demographically induced rates of return. Elmendorf and Sheiner (2000) reach similar conclusions for the U.S. They argue that, taking account of feedback effects through the rate of interest, the overall effects of ageing on saving may be contained.

Modelling the extent of these effects is difficult since one needs quantifiable models of capital flows. Qualitatively, it is clear that, other determinants being equal, capital will flow from the countries that age most (Germany Italy and France) to countries that age least (Ireland and Turkey within the OECD). Because Turkey will reach Japan in size about the year 2030, Turkey can absorb a lot of capital in form of foreign direct investment. Population-ageing related capital flows play a relatively minor role for the UK and the U.S. This balance, however, could change dramatically if large countries such as India or China start offering productive investments that can be channelled though a global capital market.

\section{c. A Synthesis}

Figures 4.2 and 4.3 display a startling contradiction. The shift-share analysis of composition changes, based on the assumption that the empirical age-specific saving rates remain as they are, implies very little decline in Germany, and even a rise in the U.S. and Japanese saving rates 
at least until 2020. The predictions of the macroeconomic growth model, based on the theoretically derived aggregate saving rate implied by intertemporal substitution and permitted to adapt to population ageing, implies a strong decline in the aggregate saving rate already until 2020.

Which of the two predictions is more likely to happen? The honest answer is that we do not know. The shift-share projections are certainly wrong because they ignore feedback effects of population ageing on saving behaviour. However, they are based on realistic age-saving profiles. In turn, the projections derived from the macro model are based on a tight and counterfactual structural model of intertemporal substitution that effectively mimics the life-cycle model of saving in young and dissaving in old age. In turn, this model captures some important feedback effects. The correct way is to combine the macroeconomic feedback model with a structural model of saving behaviour that generates the age-saving profiles of Figure 4.1. We do not have such a model yet.

\section{Conclusions: What we Know, What we Don't Know}

In this paper we discussed three key policy issues of the ongoing debate on the saving behaviour of European household: pension reform, the recent evolution of "new" financial and insurance markets, and the overall volume of savings. A key finding is that economic analysis, particularly when quantitative results for Continental Europe are required, quickly faces an impasse due to the lack of complete and satisfactory longitudinal data.

We have surveyed the ongoing debate on the role of private saving versus public pay-as-yougo pensions in old-age provision. From simulation studies calibrated on German data we have learned that freezing current PAYG contributions requires a funded component of about one third of the existing benefits. This corresponds to an increase in the saving rate between $1.8 \%$ and $3.2 \%$ of the current rate. It is much harder to judge how much of this is "new saving" or whether it simply crowds out other forms of capital accumulation. In fact, the econometric evidence does not allow us to draw firm conclusions on the degree of substitutability between public pension "mandatory saving" and private saving. The picture is further blurred by tax incentives provided in some countries to some forms of capital accumulation, hence making it even harder to reach a conclusion on whether tax incentives on pension assets will encourage this form of saving and contribute to the creation of new saving. Overall, the available evidence 
seems to point to an increase in households' saving in response to the recent retrenchment process of public pension schemes.

Another hard question is whether the recent developments of European financial markets, coupled with the advent of the EMU, have affected and will affect capital accumulation. We provide examples of some important changes in the financial landscape that have taken place over the past decades, leading to more developed credit markets, particularly mortgage markets and consumer credit arrangements. Economic theory suggests that these developments should help reducing liquidity constraints and allow constrained consumers to implement their saving decisions with a consequent reduction of "accidental saving". Furthermore financial markets should in turn benefit from "thick markets" positive externalities and from the reduced transaction costs of the single currency, hence making credit availability even more widespread. Consumers may also change in substantial way their portfolio of risky and non risky assets as a result of changes in financial markets: an increasing demand for stocks and shares may therefore contribute to new savings. The existing evidence on the relationship between saving and credit market arrangements is often cursed by the problem of correctly identifying the true causes of observed patterns in household behaviour. However, our analysis suggests that future research will be in a much better position to answer this question as the full impact of the onset of the EMU can be observed and at the same time household will be used to managing their portfolio.

Overall we find that in studying saving behaviour and the effects of public policy on it, theoretical models and simulation studies deliver useful information and qualitative policy prescriptions. However, the lack of good quality longitudinal data of European households strongly impedes empirical research that could deliver quantitative results and permit judgements on the dominance of opposing effects. Longitudinal data is essential here because saving takes place over the life-cycle. Cross sectional data - i.e., data in just one point of time - are obviously unable to identify life-cycle behaviour. Only longitudinal data can enable researchers to draw conclusions on the effects of pension reforms and welfare reforms on saving, on the interaction of credit markets arrangements and liquidity constraints, and on the role of precautionary and bequest motives alongside the traditional life cycle motives in explaining choices. 


\section{References}

Abel, A.B., N.G. Mankiw, L.H. Summers, and R.J. Zeckhauser (1989), Assessing Dynamic Efficiency: Theory and Evidence, Review of Economic Studies, 56, 1-20.

Alessie R., M. Devereux and G. Weber (1997), Intertemporal consumption, durables and liquidity constraints: A cohort analysis, European Economic Review, 41, 37-59

Alessie, R., A. Kapteyn and F. Klijn (1997), Mandatory pensions and personal savings in the Netherlands, De Economist, 145, no. 3, pp. 291-324.

Alessie, R. S. Hochguertel and A. van Soest, (2001), Household Portfolios in the Netherlands, in: L. Guiso, M. Haliassos and T. Jappelli (eds.), Household Portfolios, Cambridge, Mass.: MIT-Press, in press.

Ando A., L. Guiso and I. Visco (1994), Introduction, in: A. Ando, L. Guiso and I. Visco (eds.), Saving and the Accumulation of Wealth, Cambridge University Press, Cambridge.

Attanasio , O. and T. De Leire (1994), IRAS and household saving revisited: some new evidence, NBER working paper 4900.

Attanasio O. and A. Brugiavini, (1997), L'effetto della Riforma Amato sul risparmio delle famiglie italiane, Ricerche Quantitative per la Politica Economica-1995, Banca d'Italia-CIDE (eds.), Roma

Attanasio O. and G. Weber (1994), The UK Consumption Boom: Aggregate Implications of Microeconomic Evidence, Economic Journal, vol. 104

Attanasio O., and J. Banks (1998), Trends in household saving don't justify tax incentives to boost saving, Economic Policy, October.

Auerbach, A.J., and L.J. Kotlikoff (1983), An examination of empirical tests of social security and savings, in: E. Helpman et al. (eds.) Social Policy evaluation: an Economic Perspective, Academic Press, New York, 161-179

Auerbach, A.J. and L.J. Kotlikoff (1987), Dynamic Fiscal Analysis, Cambridge University Press, Cambridge, England.

Auerbach, A.J., L.J. Kotlikoff, Hagemann, R.G., and G. Nicoletti (1989), The Economic Dynamics of an Ageing Population: The Case of Four OECD Countries, OECD Economic Studies No. 12.

Banks, J. and S. Tanner (1999), Household Saving in the UK, Institute for Fiscal Studies, London

Banks, J., R. Blundell and S. Tanner (1998), Is There a Retirement-Savings Puzzle? American Economic Review 88(4), pages 769-88.

Barro R. J. (1974), Are Government Bonds Net Wealth?, Journal of Political Economy, $82,5,1095-117$

Bernheim B.D. (1987a), The Economic Effects of Social Security: Toward a Reconciliation of Theory and Measurement, Journal of Public Economics, 33, 273-304 
Bernheim B.D. (1987b), Dissaving After Retirement: Testing the Pure Life Cycle Hypothesis, in Z. Bodie, J.Shoven and D.Wise, eds. Issue in Pension Economics, NBER, The University of Chicago Press, Chicago.

Birg, H., and A. Börsch-Supan (1999), Für eine neue Aufgabenteilung zwischen gesetzlicher und privater Altersversorgung, GDV: Berlin.

Blommestein H.J. and N. Funke, eds. (1998), Institutional Investors and the new Financial Landscape, OECD, Paris

Boeri, T., A. Börsch-Supan und G. Tabellini (2001), Would you Like to Shrink the Welfare State? The Opinions of European Citizens. Economic Policy, 32, in press.

Börsch-Supan, A. (1992): Saving and consumption patterns of the elderly: the German case. Journal of Population Economics, 5, 289-303.

Börsch-Supan, A. (1994): Savings in Germany - Part II: Behavior. In: Poterba, J. (ed.), International Comparisons of Household Savings. Chicago, London: University of Chicago Press, 207-236.

Börsch-Supan, A. (1995), Regional Development, Capital Flows, and Trade Policies in an Aging Europe, in: B. Gahlen, H. Hesse, H.J. Ramser, Neue Entwicklungen in der Regionalökonomik, J.C.B. Mohr (Paul Siebeck) Tübingen, forthcoming.

Börsch-Supan, A. (1996), The Impact of Population Ageing on Savings, Investment and Growth in the OECD Area. In: OECD, Future Global Capital Shortages: Real Threat or Pure Fiction? Paris: OECD, 103-141.

Börsch-Supan, A. (1999), Zur deutschen Diskussion eines Übergangs vom Umlage- zum Kapitaldeckungsverfahren in der Gesetzlichen Rentenversicherung. Finanzarchiv, Band 55, Heft 3, S. 400-428.

Börsch-Supan, A. (2000), A Model under Siege: A Case Study of the Germany Retirement Insurance System, The Economic Journal, Vol. 110 No. 461, F24-45.

Börsch-Supan, A., ed. (2001a), International Comparisons of Household Saving: A Study of Life-Cycle Savings in Seven Countries, New York: Academic Press.

Börsch-Supan, A. (2001b), The German Savings Puzzle, Research in Economics, 55, in press.

Börsch-Supan, A. und M. Lührmann (2000), Prinzipien der Renten- und Pensionsbesteuerung, Frankfurter Institut: Bad Homburg.

Börsch-Supan, A. and M. Miegel, eds. (2001), Pension Reform in Six Countries, Springer: Berlin, Heidelberg, New York.

Börsch-Supan, A. und A. Reil-Held (1998), Retirement Income: Level, Risk, and Substitution among Income Components. In: OECD (ed.), Maintaining Prosperity in an Ageing Society. Paris: OECD, AWP 3.7, 1-21.

Börsch-Supan, A., and K. Stahl (1991): Life-cycle savings and consumption constraints. Journal of Population Economics, 4, 233-255.

Börsch-Supan, A. and J. K. Winter (1999), Pension Reform, Savings Behavior and Corporate Governance. Arbeitspapier Nr. 99-48, Sonderforschungsbereich 504, Universität Mannheim. 
Börsch-Supan, A., F. Heiss und J. K. Winter (2001), Pension Reform, Capital Markets, and the Rate of Return, mimeo, University of Mannheim and Herbert-Giersch-Stiftung, Magdeburg.

Börsch-Supan, A., R. Palacios und P. Tumbarello, 1999, Pension Systems in the Middle East and North Africa: A Window of Opportunity, Arbeitspapier The World Bank und SFB Nr. 99-44, Universität Mannheim.

Breyer, F. (2000), Kapitaldeckungs- versus Umlageverfahren, Perspektiven der Wirtschaftspolitik.

Brugiavini, A., and G. Weber (1994): Durables and non-durables consumption: evidence from Italian household data, In: Ando A., L. Guiso and I.Visco. (eds.), Saving and the Accumulation of Wealth, Cambridge: Cambridge University Press.

Brugiavini, A. (1987), Empirical Evidence on Wealth Accumulation and the Effects of Pension Wealth: an Application to Italian Cross Section Data", 1987, Financial Markets Group, D.P. 20, LSE, London.

Brugiavini, A., and G. Weber (2001): Household Savings: Concepts and Measurement. In: Börsch-Supan, A. (ed.), International Comparisons of Household Saving, New York: Academic Press.

Brugiavini A. and E. Fornero, (2001), Pension Provision in Italy, forthcoming in: R. Disney and P. Johnson, Eds., Pension systems and retirement incomes across OECD countries, Edward Elgar, London.

Chiuri M.C and T. Jappelli (2000), Financial Markest Imperfections and Homeownership: an International Comparison, CSEF working paper, Salerno.

Cutler, D.M., J.M. Poterba, L.M. Sheiner and L.H. Summers, 1990, An Aging Society: Opportunity or Challenge?, Brookings Papers on Economic Activity.

Davies E. (1995) Pension funds, retirement- income security and capital markets, an international perspective, Oxford University Press, Oxford.

Davies E. (1998), Pension fund reform and European financial markets, Financial Markets Group, LSE, Special paper no. 107

Dilnot A., R. Disney, P. Johnson and E. Whitehouse (1994), Pension Policy in the UK, An economic analysis, Institute for Fiscal Studies, London, UK

Dilnot, A.W. (1992): Taxation of Private Pensions: Costs and Consequences. In: OECD, Private Pensions and Public Policy, Paris: OECD.

Disney, R., (1996), Can We Afford to Grow Older?, The MIT Press, Cambridge

Disney, R., M. Mira D’Ercole and P. Scherer (1998), Resources during retirement, OECD, Ageing Working paper, AWP 4.3, Paris

Disney, R. (2000), Crises in OECD Public Pension Programmes: What Are the Reform Alternatives?, Economic Journal Features, 110 February, F1-F23

Disney R. and P. Johnson, (2001), Pension systems and retirement incomes across OECD countries, Edward Elgar, London.

Elmendorf D.W and L.M. Sheiner, (2000), Should America Save for its Old Age? Fiscal Policy, Population Aging, and National Saving, Journal of Economic Perspectives, vol.14. no. 3, 57-74 
European Commission, (1999) Towards a single market for supplementary pensions. Results of the consultation on the Green Paper on Supplementary pensions in the single market, $\operatorname{COM}(1999), 134$.

Euwals, R. (2000) 'Do Mandatory Pensions Decrease Household Savings: Evidence for the Netherlands.' De Economist, Vol. 148, pp 643-670.

Eymann, A., and A. Börsch-Supan (2001), Household Portfolios in Germany, in: L. Guiso, M. Haliassos and T. Jappelli (eds.), Household Portfolios, Cambridge, Mass.: MIT-Press.

Feldstein, M. (1974), Social Security, Induced Retirement and Aggregate capital accumulation, Journal of Political Economy, 82,5, 905-926

Feldstein, M. (1998). Privatizing Social Security. Chicago: The University of Chicago Press.

Gale W.J. and J.K. Scholz (1994) IRAs and household saving, American Economic Review, $84,1233-1260$

Guiso L. and T. Jappelli (1994), Intergenerational Transfers and capital market imperfections, Evidence from a cross-section of Italian households, in A. Ando, L. Guiso and I. Visco (eds.), Saving and the Accumulation of Wealth, Cambridge University Press, Cambridge.

Guiso L. and T. Jappelli (2000), Private Transfers, Borrowing Constraints and the Timing of Homeownership, CFES working paper 17, Salerno

Gruber, J., and D. Wise, eds., (1999), Social Security and Retirement Around the World, The University of Chicago Press: Chicago.

Hamermesh D.S (1982), Consumption during retirement: the missing link in the Life Cycle, NBER working paper 930.

Hayashi, F. (1987), Tests for liquidity constraints: a critical survey and some new observations, in T.F. Bewley (ed.), Advances in Econometrics, Fifth World Congress, Vol.2, Cambridge University Press.

Hayashi, F., T. Ito and J. Slemrod (1988), Housing finance imperfections, taxation and private saving: a comparative simulation analysis of the United States and Japan, Journal of Japanese and International Economies, 2, 215-238.

Heller, P., 1989, Aging, Savings and the Sustainability of the Fiscal Burden in the G7countries: 1980-2025. IMF.

Hendershott, P. (1991), Are Real House Prices Likely to Decline by 47 Percent? Regional Science and Urban Economics 21(4), 553-63.

Holzmann, R. (1997), Pension Reform, Financial Market Development and Endogenous Growth: Preliminary Evidence from Chile, IMF Staff Papers.

Hubbard R.G., (1986) Pension wealth and individual saving, some new evidence, Journal of Money Credit and Banking, 18, 167-178

Jappelli T., and M. Pagano (1994), Saving Growth and Liquidity Constraints, Quarterly Journal of Economics, 109, 83-109

Jappelli T. (1995), Does social security wealth reduce the accumulation of private wealth? Evidence from Italian survey data, Ricerche Economiche, 49,1-31

Jappelli T, and L. Pistaferri, (2000), Risparmio e Scelte Intertemporali, Il Mulino, Bologna 
Kapteyn, A., R. Alessie and A. Lusardi (1999), "Explaining the wealth holdings of different cohorts: productivity growth and social security", mimeo, Tinbergen Institute.

King M. and L. Dicks-Mireaux, (1982), Asset Holding and the Life Cycle, Economic Journal, 92

Kohl, R. and P. O'Brien (1998), The Macroeconomics of Ageing, Pensions and Savings: A Survey, OECD Working Paper AWP1.1, Paris.

Kotlikoff L.J. and A. Spivak, (1981) The family as an incomplete annuity market, Journal of Political Economy, 89.

Kotlikoff L.J., Spivak A. and L.H. Summers (1982), The adequacy of savings, American Economic Review, 72, 1056-1079.

Laboul, A. (1998), Private Pension Systems: Regulatory Policies, OECD Working Paper $A W P 2.2$, Paris.

Laibson D., A. Repetto and J. Tobacman (1998), Self-control and saving for retirement, Brooking Papers in Economic Activity, 1-98, pp. 91-196.

Mankiw, N.G. and D.N. Weil (1989), The Baby Boom, the Baby Bust, and the Housing Market, Regional Science and Urban Economics 19(2), 235-58.

McKinsey Global Institute (1994), The Global Capital Market: Supply, Demand, Pricing and Allocation, Washington, D.C.

Modigliani, F. and R. Brumberg (1954), Utility Analysis and the Consumption Function: An Interpretation of Cross-section Data. In: Kurihara, K. (ed.), Post-Keynesian Economics. New Brunswick, NJ: Rutgers University Press.

Muellbauer, J. and A. Murphy, (1990) Is the UK Balance of Payments Suistainable?, Economic Policy, vol.11,pp.345-83

OECD (1988), Ageing Populations: The Social Policy Implications, Paris.

OECD (1996), Future Global Capital Shortages: Real Threat or Pure Fiction? Paris: OECD, 103-141.

OECD (1998), Maintaining Prosperity in an Ageing Society, Paris.

OECD (2000a), Reforms for an Ageing Society, Paris.

OECD (2000b), Economic Outlook, vol. 67, Paris.

Pagano, M. (1993), The flotation of companies on the stock market: a coordination failure model, European Economic Review, 37.

Rossi N. and I. Visco (1994): Private Saving and the Government deficit in Italy, In: Ando A., L. Guiso and I.Visco. (eds.), Saving and the Accumulation of Wealth, Cambridge: Cambridge University Press.

Sinn, H.W. (2000), Why to Fund and Why Not to Fund, mimeo, CES, Munich

Skinner, J. und R.G. Hubbard (1996), Assessing the Effectiveness of Saving Incentives, Journal of Economic Perspectives 10(4), 73-90.

Venti S. and D. Wise (1990), Have IRAs increased U.S. Savings? Evidence from consumer expenditure surveys, Quarterly Journal of Economics, 105, 661-98. 
Wise, D.A. (2001), United States Support in Retirement: Where We Are and Where We Are Going, in: Börsch-Supan, A. and M. Miegel, eds. (2001), Pension Reform in Six Countries, Springer: Berlin, Heidelberg, New York.

World Bank (1994), Averting the Old Age Crisis; Policies to Protect the Old and Promote Growth, The World Bank, Washington.

World Bank (1999): The Tax Treatment of Funded Pensions, World Bank Pension Reform Primer 2.3, Washington, D.C. 


\section{Discussion Paper Series}

Mannheim Research Institute for the Economics of Aging Universität Mannheim

To order copies, please direct your request to the author of the title in question.

\begin{tabular}{|c|c|c|c|}
\hline Nr. & Autoren & Titel & Jahr \\
\hline 01-02 & Axel Börsch-Supan & $\begin{array}{l}\text { Eine Blaupause für eine nachhaltige } \\
\text { Rentenreform in Deutschland }\end{array}$ & 02 \\
\hline $02-02$ & Axel Börsch-Supan & A Blue Print For Germany's Pension Reform & 02 \\
\hline 03-02 & Axel Börsch-Supan & $\begin{array}{l}\text { Reduction of Working Time: Does it Decrease } \\
\text { Unemployment? }\end{array}$ & 02 \\
\hline 04-02 & Axel Börsch-Supan & $\begin{array}{l}\text { Übergang statt Untergang: Wider die Furcht vor } \\
\text { dem Untergang der Arbeit }\end{array}$ & 02 \\
\hline 05-02 & $\begin{array}{l}\text { Daniel Houser, } \\
\text { Joachim Winter }\end{array}$ & $\begin{array}{l}\text { How Do Behavioral Assumptions Affect Structural } \\
\text { Inference? Evidence Form A Laboratory } \\
\text { Experiment }\end{array}$ & 02 \\
\hline 06-02 & Axel Börsch-Supan & $\begin{array}{l}\text { International Comparison of Household Savings } \\
\text { Behaviour: The German Savings Puzzle }\end{array}$ & 02 \\
\hline 07-02 & \begin{tabular}{|l|} 
Tito Boeri, \\
Axel Börsch-Supan, \\
Guido Tabellini \\
\end{tabular} & $\begin{array}{l}\text { Would you Like to Reform the Pension System? } \\
\text { The Opinions of European Citizens }\end{array}$ & 02 \\
\hline $08-02$ & $\begin{array}{l}\text { Axel Börsch-Supan, } \\
\text { Florian Heiss, } \\
\text { Miki Seko } \\
\end{array}$ & $\begin{array}{l}\text { Housing Demand in Germany and Japan } \\
\text { Paper in memoriam of Stephen King }\end{array}$ & 02 \\
\hline $09-02$ & $\begin{array}{l}\text { Moshe Ben-Akiva, } \\
\text { Daniel McFadden, } \\
\text { Kenneth Train, } \\
\text { Axel Börsch-Supan, } \\
\text { et.al. }\end{array}$ & Hybrid Choice Models: Progress and Challenges & 02 \\
\hline $10-02$ & \begin{tabular}{|l} 
Axel Börsch-Supan, \\
Alexander Ludwig, \\
Joachim Winter \\
\end{tabular} & Aging and International Capital Flows & 02 \\
\hline $11-02$ & Axel Börsch-Supan & Labor market effects of population aging & 02 \\
\hline $12-02$ & Axel Börsch-Supan & $\begin{array}{l}\text { Kann die Finanz- und Sozialpolitik die } \\
\text { Auswirkungen der Bevölkerungsalterung auf den } \\
\text { Arbeitsmarkt lindern? }\end{array}$ & 02 \\
\hline 13-02 & $\begin{array}{l}\text { Florian Heiß, } \\
\text { Jens Köke }\end{array}$ & $\begin{array}{l}\text { Dynamics in ownership and firm survival: } \\
\text { Evidence from corporate Germany }\end{array}$ & 02 \\
\hline $14-02$ & Axel Börsch-Supan & $\begin{array}{l}\text { "Global Aging" an der Jahrtausendwende: } \\
\text { Die demographischen Herausforderungen des } \\
\text { 21. Jahrhunderts }\end{array}$ & 02 \\
\hline $15-02$ & Axel Börsch-Supan & $\begin{array}{l}\text { Nach der Reform ist vor der Reform: Weitere } \\
\text { Schritte für eine nachhaltige Reform der } \\
\text { Altersvorsorge in Deutschland }\end{array}$ & 02 \\
\hline $16-02$ & Florian Heiss & Specification(s) of Nested Logit Models & 02 \\
\hline
\end{tabular}




\begin{tabular}{|l|l|l|c|}
\hline $17-02$ & Axel Börsch-Supan & $\begin{array}{l}\text { What We Know and What We Do NOT Know } \\
\text { About the Willingness to Provide Self-Financed } \\
\text { Old-Age Insurance }\end{array}$ & 02 \\
\hline $18-02$ & $\begin{array}{l}\text { Axel Börsch-Supan, } \\
\text { Agar Brugiavini }\end{array}$ & Savings: The Policy Debate in Europe & 02 \\
\hline
\end{tabular}

